\title{
Türkiye'de Çocuğun Ekonomik Değerini Etkileyen Faktörler: 2016 Aile Yapısı Araştırması Analizi Üzerinden Sosyolojik Bir Değerlendirme
}

\author{
Sutay Yavuz ${ }^{1}$, , Fuat Güllüpınar ${ }^{2}$ (C)
}

\section{Öz}

Bu çalışmanın amacı; 2016 'Aile Yapısı Araştırmasının (TAYA 2016)' verilerine dayalı olarak anne-babaların çocuklara ilişkin ekonomik beklentilerini etkileyen faktörleri analiz etmek ve bu faktörlerin güncel boyutlarını değerlendirmektir. Çalışma esas olarak Türk toplumunda uzun yıllardır yaşanan ekonomik, kültürel ve sosyal değişimlerin bağlamını dikkate alarak; bireylerin demografik, sosyoekonomik, kültürel ve yerleşim yeri özelliklerinin çocuğun ekonomik değerine/maddi faydasına atfettikleri anlamları önemli ölçüde belirlediği varsayımına dayanmaktadır. Verilerin analizi sonucunda, daha genç kuşaklardan olan, daha az çocuğu olan, daha yüksek eğitim ve sosyoekonomik statüye sahip, daha seküler tutumları benimsemiş, kent sosyal ortamında daha uzun süredir yaşayan bireylerin çocuklardan maddi/ ekonomik katkı beklenti düzeyinin daha ileri yaşlarda olan, daha düşük eğitime ve sosyo-ekonomik statüye sahip, daha dindar tutumları benimsemiş ve daha kırsal özellikte ki yerleşim yerlerinde yaşayan bireylerden anlamlı derecede düşük olduğu bulunmuştur. Sonuç olarak, Türkiye'de modernleşme dinamikleriyle birlikte, eğitimli, sosyo-ekonomik statüsü yüksek, seküler değerleri benimsemiş ve tolerans seviyesi yüksek bireylerde daha fazla olmak üzere, çocuklara yönelik eşitlikçi değerlerin öne çıktı̆ına ve özellikle çocuğun özerkliğine, bireysel yaşantısına ve başarısına verilen önemin artmasına bağlı olarak çocukluktan maddi fayda beklentisinin azaldığından bahsedilebilir.

\section{Anahtar Kelimeler \\ Aile • Çocuğun değeri • Ekonomik değer • Kuşaklararası ilişkiler • Sekülerleşme •Türkiye Aile Yapısı Araştırması \\ Factors Affecting Children's Economic Value in Turkey: A Sociological Analysis of the 2016 Family Structure Research Abstract}

This study examines the factors affecting parents' economic (material) expectations from their children in Turkey through data from the 2016 Family Structure Research (2016 Aile Yapısı Araştırması). The data analysis shows the level of economic contribution expected from children to be significantly lower for individuals from younger generations who have lived longer in an urban social environment, have fewer children, have higher education and socioeconomic statuses, and have adopted more secular attitudes compared to those from older generations who lived longer in rural settlements, have more children, have lower educational and socioeconomic statuses, and have more religious attitudes. The study indicates the financial benefits expected from children to decrease as a result of the egalitarian values that emerge in children and the increased importance given to children's autonomy, individual life, and success, especially for secular and tolerant individuals with higher socioeconomic and educational statuses.

\section{Keywords}

Economic value $\bullet$ Family Structure Research of Turkey •Intergenerational relations $\bullet$ Value of children $\bullet$ Secularization

1 Sorumlu Yazar: Sutay Yavuz (Doç. Dr.), Ankara Sosyal Bilimler Üniversitesi, Sosyal ve Beşeri Bilimler Fakültesi, Sosyoloji Bölümü, Ankara. E-posta: sutay.yavuz@asbu.edu.tr ORCID: 0000-0002-9321-0669

2 Fuat Güllüpınar (Doç. Dr.), Anadolu Üniversitesi, Edebiyat Fakültesi, Sosyoloji Bölümü, Eskişehir. E-posta: fgullupinar@anadolu.edu.tr ORCID: 0000-0003-3661-7232

Attf: Yavuz, S. ve Gullupinar, F. (2019). Türkiye'de çocuğun ekonomik değerini etkileyen faktörler: 2016 Aile Yapısı Araştırması analizi üzerinden sosyolojik bir değerlendirme. İstanbul Üniversitesi Sosyoloji Dergisi, 39(2), 379-409. https://doi.org/10.26650/SJ.2019.39.2.0101 


\section{Extended Summary}

Turkey has experienced significant social transformations such as industrialization, urbanization, economic development, raising education level, internal and external migration and globalization since the second half of the 20th century up to the present. Together with this rapid economic and social change, Turkey's social structure has transformed from traditional, rural, agricultural, and patriarchal to an industrial society with increasingly modern and urban. Despite all these changes, Turkey generally still has a family-oriented social structure (Öztan, 2014). However, the claim that the patriarchal family ideology has wholly lost influence in all segments of society is difficult to argue.

The aim of this study is to assess and evaluate what is expected economically from children based on data from the 2016 Turkish Family Structure Research carried out by the Turkey Statistical Institute (TurkStat) and the Ministry of Family and Social Policy (ASPB). The study is mainly based on the assumption that individuals' demographic, socioeconomic, cultural and residential characteristics significantly affect the meanings attributed to children's economic value/material benefit. According to this approach, the level of financial/economic contribution expected from children is argued to be significantly lower for those from younger generations who have lived longer duration in an urban social environment, have fewer children, have higher education and socioeconomic statuses and adopt more secular attitudes compared to those from older generations in rural settlement with more children, lower education and socioeconomic statuses and more religious attitudes.

\section{Methodology}

Micro-data from the 2016 Turkish Family Structure Research (TurkStat, 2016b) has been analyzed using the multinomial logistic regression model. The analysis unit consists of individuals with at least one child of their own or as a step-parent.

\section{Dependent Variable}

In the model, the participants who stated agreeing (68.5\%) with the expression "Once grown up, children should financially support their parents" have been defined as the reference category for the dependent variable.

\section{Independent Variables}

The last categories have been defined as the reference category for the independent variables.

Demographic variables. These include gender $(1=$ female; $2=$ male), age (between $15-29$ years old $=1$; between $30-39=2$; between 40 and $49=3$; and 50 or older $=4$ ) 
and number of children (one child $=1$; two children $=2$; three children $=3$; and four children and above $=4$ ).

Socioeconomic variables. These include education level (university level or higher $=1$, high school $=2$, primary/secondary school $=3$, and never finished grade school $=4$ ) and household income level (highest $=1$, high $=2$, upper middle $=3$, lower middle $=4$, low $=5$, and lowest $=6$ ).

Cultural attitude variables. These variables involve: Gender preference for an only child (respondents were asked to answer the question, "If you were to have only one child, what would you want your child's gender to be?" with answers rated as girl $=1$, boy $=2$, and doesn't matter $=3$ ), the impact of religious belief on life (index variable where no impact $=1$, low impact $=2$, moderate impact $=3$, and high impact $=4$ ), and tolerance levels (index variable where tolerant $=1$, partially tolerant $=2$, and not tolerant $=3$ ).

NUTS-1 Regions. These include the place where one resided until the age of 15 $($ Provincial center $=1$, District center $=2$, Overseas $=3$, and town $/$ village $=4)$ and NUTS-1 geographical regions (Istanbul $=1$, Western Marmara $=2$, Aegean $=3$, Eastern Marmara $=4$, Western Anatolia $=5$, Mediterranean $=6$, Central Anatolia $=7$, Western Black Sea $=8$, Eastern Black Sea $=9$, Northeast Anatolia $=10$, Middle-East Anatolia $=11$, and Southeast Anatolia $=12$ ).

No multicollinearity has been found among the independent variables.

\section{Results}

Our study has shown the last model containing the independent variables to perform better than the fixed model (intercepts only). All the independent variables included in the model contribute significantly to the model itself.

Gender. Female respondents tend to disagree with the expression "Once having grown up, children should financially support their parents" (the dependent variable) $26 \%$ more than male respondents.

Age. Younger respondents tend to disagree with this expression significantly more than respondents 50 years and older.

Number of child. Respondents with one or two children tend to disagree with this expression significantly more than respondents with three or more children.

Education level. Respondents with high school or higher education levels tend to disagree with this expression significantly more than respondents with lower education levels. 
Household welfare level. The higher one's household welfare level, the higher the probablity one will disagree with this expression.

Gender preference for an only child. Taking the answer "It doesn't matter" as the reference point, those who prefer a daughter tend to disagree with the expression (dependent variable) 14\% more.

The effect of religious beliefs on life practices. A negative and significant relationship has been detected between the level of the effect of religious belief on life practices with the tendency to disagree with the expression. Thus, the expected level of financial contribution is significantly lower among respondents with more secular attitudes compared to those with religious ones.

Tolerance level. Those who responded being more tolerant of differences in malefemale relations and marriage tend to disagree with the expression "Once having grown up, children should financially support their parents" significantly more than those who responded as not being tolerant.

Type of place of residence Residence locale until the age of 15 . Respondents who resided in urban locales such as "provincial centers" and "district centers" longer until the age of 15 tend to disagree or partially agree with this expression significantly more than respondents who had lived mostly in "town" or "village settlements."

NUTS-1 Regions: Every region of Turkey tends to disagree with this expression more compared to the Southeast Anatolian Region which is the reference category of the research.

\section{Discussion and Conclusion}

The vast majority of women in Turkey are not included in the labor force. Therefore, most women do not have direct social security. Thus, women in Turkey have relatively lower incomes than men in general and are mostly covered by social security through their husbands/fathers. However, the findings from the model show that, while keeping all other variables being kept under control, women tend to reject expecting children to contribute economically to their parents more than men. One noteworthy finding from the study is that despite their relatively less secure socioeconomic conditions, women are more inclined than men to change the traditional social acceptance.

When evaluating participants' approaches with respect to age group and number of children, our model's findings are seen to overlap with the findings from previous studies. Participants younger than middle-aged with one or two children tend to have lower economic expectations from their compare to those middle-aged and older with 
more than two children. The same situation is valid for the socioeconomic and residence variables we used in our study; participants with higher education and economic status levels who have lived longer in urban areas have significantly lower expectations of economic contributions from their children when they grow up compared to those with lower education and economic status levels who have lived longer in rural areas. This finding is also consistent with the results from previous studies.

The model demonstrates that the more secular and more tolerant participants differ from the more religious and less tolerant participants by "not having economic expectations from children." Therefore, even among individuals with similar socioeconomic conditions, having different cultural attitudes and thoughts can have an impact that is able to vary perceptions and expectations regarding children. This finding is the current study's most original contribution to the relevant literature. Our study shows that socio-cultural tendencies and attitudes in particular should be taken into consideration in studies on the values and perceptions attributed to children.

In conclusion, our study demonstrates one of the most important changes in the family structure in Turkey to be the decrease in economic expectations from children as a result of variations in demographics, education level, and economic status; increased prosperity and secularization; increased tolerance toward differences; and the urbanization of the population. As a matter of fact, this situation is closely related to the fact that children in today's globalized world of consumption have turned into a consumer issue that causes certain expenses for families rather than providing economic benefits. 


\section{Türkiye'de Çocuğun Ekonomik Değerini Etkileyen Faktörler: 2016 Aile Yapısı Araştırması Analizi Üzerinden Sosyolojik Bir Değerlendirme}

Türkiye 20. yüzyılın ikinci yarısından günümüze; endüstrileşme, kentleşme, ekonomik kalkınma, eğitim düzeyinin artması, iç ve dış göç ve küreselleşme gibi önemli sosyal değişimleri yaşamakta olan bir ülkedir. Bu ekonomik ve sosyal değişikliklerle birlikte Türkiye'nin toplum yapısı, geleneksel, kırsal, tarımsal ve ataerkil bir toplumdan giderek daha modern, şehirli, demografik geçişini tamamlamış ve endüstriyel bir toplum biçimine dönüşmektedir (Koç ve ark., 2010; Pamuk, 2014; Sunar ve Fişek, 2005).

Türkiye' de geçen yüzyılın ortalarında nüfusun ancak dörtte biri kentlerde yaşarken, günümüzde kentli nüfus toplam ülke nüfusunun dörtte üçüne ulaşmıştır (Koç, ve ark., 2010). 1950'li yıllardan günümüze hız kazanan sanayileşme ve tarımda verimlilik artışı ekonomik büyümeyi beraberinde getirmiştir. 1950 yılından 2010 yılına kadar tarımsal üretimin gayrı safi milli hasılaya oranı \%42'den \%9'a (Pamuk, 2014), 2018 y1lı itibari ile de \%6’ya gerilemiştir (TÜİK, 2018a). Kişi Başına Gayri Safi Yurtiçi Hasıla; 1950'lerde 160 Dolar seviyesinde iken 2010'dan itibaren 10000 Dolar üzerine çıkmıştır (TÜIKK, 2018b). Ortalama gelir seviyesindeki artış, bireylerin sağlık ve eğitim seviyelerinin yükselmesini sağlamıştır. Doğuşta beklenen yaşam süresi 1950'lerin başındaki 44 iken, 2016-2018 döneminde 78 yıla ulaşmıştır (erkekler için 75,6 ve kadınlar için 81,0) (TÜIKK, 2019a). Nüfus yaşlanması göstergelerinden "ortanca yaş", 2000'li yılların başında 26 iken 2018' de 32'ye yükselmiş, yaşlı nüfusun (65+) toplam nüfus içindeki oranı da 2018 yılında \%8,8 olmuştur. Eğitim alanında ise 1950'lerde yetişkin başına düşen ortalama eğitim süresi 1,4 yıl iken 2010' yılında bu rakam 6,5 y1la çıkmıştır (Pamuk, 2014).

Yaşanan bu ekonomik ve sosyal değişimler özellikle tarımdaki üretim biçiminin ve kırdaki ailenin üretim işlevinin zaman içinde değişmesine yol açmıştır (Özbay, 2015). 1950'li yıllarda endüstriyel üretimin artması ve tarımsal üretimin teknolojik aletlerle yapılmasıyla birlikte kırdan kente göç olgusu ortaya çıkmıştır. Kentleşmenin yanı sıra istihdam yapısının değişmesi, sosyal güvenlik sisteminin herkesi kapsayacak şekilde gelişmesi de ataerkil geniş aile yapısının zayıflamasına neden oluşturmuştur (Koç, 2018, s. 77). Böylelikle aile ve hanehalkı kompozisyonları da değişmeye başlamıştır. 1960'l1 yıllardan günümüze değin gerçekleştirilen araştırma ve nüfus sayımı verileri, son 40-50 yıl içinde "çekirdek" ve "dağılmış aile” oranının arttığını, "geniş" aile oranının ise azaldığını ortaya koymaktadır'. Günümüzde özellikle "tek ebeveynli aile" ve "tek kişilik hanehalkı”" oranlarındaki artış dikkat çekicidir (Koç, 2018, s. 36). Son

1 Çekirdek aile "karıkoca ve/veya evlenmemiş çocuklardan oluşan aile biçimi”" iken 'dağılmış aile'; "çekirdek aile biriminin tek kişiye, tek ebeveyne dönüşmüş olduğu ya da aralarında kan bağı olan ya da olmayan kişilerden oluşan aile" biçimidir. Geniş aile ise "çekirdek aile birimine yatay, dikey ya da düşey olarak eklenmiş diğer bir kişinin ya da ailenin bulunduğu aile biçimidir". Her bir kategorinin alt sınıfları için bakınız (Koç, 2014). 
on yılda yapılan çalışmalar, Türkiye'de çekirdek aile oranın \%65-70, dağılıış aile oranın \%18-20 ve geniş aile oranının da \%12-15 civarında olduğunu göstermektedir (Koç, 2014; TÜİK, 2019b). 1960'lı yılların sonunda 5,5 olan ortalama hanehalk1 büyüklüğü ise yaklaşık yarım asırda ortalama iki kişi azalarak 2018 yılında 3,4 olmuştur (TÜİK, 2019b; Yavuz, 2002).

Türkiye'de toplumsal değişme ve modernleşme sürecinin etkilediği bir diğer alan "aile kurma" örüntülerini ifade eden evlenme ve çocuk sahibi olma davranışları ile ailenin dağılmasını ifade eden "boşanma” davranışlarıdır. Özellikle 1980’li yıllardan günümüze evlenilecek kişinin bulunması, evlilik kararının alınması ve evlenme biçimindeki tercihlerde, geleneksel bazı kalıplar sürdürülmekle birlikte, giderek ‘bireyselleşmenin' etkisinin baskın olduğu modeller öne çıkmaktadır (ASPB, 2015).

Türkiye'de evlilik halen önemini kaybetmeyen, kadın ve erkeğin birlikte yaşamasında neredeyse yegâne meşru kabul edilen birliktelik biçimidir. Bununla birlikte Türkiye'de bireyler ilk evliliklerini giderek daha ileri yaşlarda gerçekleştirmektedirler. Örneğin, 1978 yılında gerçekleştirilen nüfus araştırmasında 20-24 yaş grubu kadınların yaklaşık \%73,8'i, 25-29 yaş grubu kadınların da \%92,5'i evli bulunmuştur. 2018 yılında yapılan benzer bir araştırmada ise 20-24 yaş grubu kadınların \%39,7'si ve 25-29 yaş grubu kadınların da \%71,2'si evli olarak tespit edilmiştir (ASPB, 2015, s.15; HÜNEE, 2019, s. 49). TÜIKK istatistiklerine göre de 2001 yılında erkekler için 27,6 ve kadınlar için 23,4 olan 'ortalama ilk evlenme yaşı', 2018 yılında erkekler için 30,2 ve kadınlar için de 26,5'dir (TÜIK, 2018c). Benzer şekilde çocuk sahibi olma davranışında da önemli değişimler olmuştur; 1960'lı y1llarda 5 ve 6 arası olan toplam doğurganlık hızı² (TÜIKK, 2019c), 1990'lı yılların başına kadar hızla daha sonra da nispeten yavaşlayarak azalmaya devam etmiş 2000'li yılların başından beri yenilenme düzeyinin (2,1 çocuk) üstünde neredeyse durağan hale gelmiştir. 2018 Türkiye Nüfus ve Sağlık Araştırması bulgularına göre, 2013-2018 döneminde Türkiye genelinde toplam doğurganlık hızı 2,3 olup bu oran kentsel alanlarda 2,2 ve kirsal alanlarda 2,8'dir (HÜNEE, 2019, s.55).

Diğer yandan Türkiye'de evlenen çiftlerin geçmişe göre daha sık boşandıkları görülmektedir. 2001 yılında binde 1,41 olan kaba boşanma hızı ${ }^{3} 2018$ yılında binde 1,75'e yükselmiştir (TÜIK, 2019d). Boşanmalar ağırlıklı olarak (neredeyse \%40’1) evliliklerin ilk beş yılı içinde gerçekleşmektedir. Buna karşın, boşanan bireyler arasında yeniden evlenme sayısı ve oranı da zaman içinde artmaktadır. Nitekim her yıl gerçekleşen evlenmelerin yaklaşı \% 15 'i boşandıktan sonra yeniden evlenen kişilerce gerçekleştirilmektedir. Yani, boşanan bireylerin bir bölümü eğer koşulları uygunsa yeniden evlenmektedirler (ASPB, 2015, s.23).

2 Toplam doğurganlık hızı, bir kadının doğurgan olduğu dönem olan 15-49 yaş grubunda doğurabileceği ortalama çocuk sayısıdır (TÜİK, 2019c).

3 Kaba boşanma hızı, belli bir yıl içinde her 1000 nüfus başına düşen boşanma sayısıdır (TÜİK, 2019d). 
Sonuç olarak Türkiye'de 1950’lerden günümüze devam eden dönemde üretim yapısının değişmesi, sosyo-ekonomik düzeyde görece refah artışı ve kentleşme dinamikleri her alanda toplumsal değişimi hızlandıran bir etkiye sahip olmuştur. Türkiye'deki bu modernleşme dinamikleri deneyimi, toplumun aile ve nüfus yapısında da güçlü dönüşümler sağlamıştır. Bu dönüşümün önemli bir boyutunu ise geleneksel aile içindeki nesiller ve cinsiyetler arası ilişkilerin farklılaşması oluşturmaktadır. Kentleşen ve modernleşen bu toplumda toplumsal cinsiyet ilişkileri açısından eşitlikçi yaşam tarzı talebi öne çıkmış, özerklik, bağımsızlık ve bireyselleşme çocuk ve gençler arasında yaygın bir eğilim olmaya başlamıştır. Boşanma oranlarının artmasıyla tek ebeveynli çocuk sayısı da artmıştır. Nitekim Türkiye'deki bu toplumsal ve kültürel değişimler özellikle 2000'li yıllardan sonra ülkenin orta sınıfında diğer ülkelerde olduğu gibi giderek görünürlük kazanmıştır (Sunar ve Fişek, 2005).

Buna karşın, söz konusu süreçleri Türkiye'de toplumun homojen bir şekilde tecrübe ettiği söylenemez. Öztan'ın (2014, s. 179) da vurguladığ 1 üzere, Türkiye'de toplumun geneli hala "aileci bir toplumdur". Aile yapısının ve aileye ilişkin tutumların kuşaklar ve cinsiyetler arasında daha eşitlikçi bir yapıya doğru dönüşmesine karşın erkeklerin egemenliğine dayalı ataerkil aile ideolojisinin bütünüyle veya tüm toplum kesimlerinde etkisini kaybettiğini iddia etmek güçtür.

\section{Ebeveynlerin Çocuğa Yönelik Algıları}

Günümüz Türkiye'sinde aile toplumunda aile esas itibari ile çocuk merkezli bir yapı olarak kavramsallaştırılmakta ve buna bağlı olarak da gerek evlilik gerekse aile içi pek çok diğer ilişki çocuk temelli sosyal ilişki olarak yaşanmaktadır (BASAGM, 2010). Tıpk1 aile gibi ‘çocukluk' da sosyal ve kültürel koşullara bağlı olarak inşa edilen sosyolojik bir olgudur. Bundan dolayı da sosyal ve kültürel koşulların farklılığına bağlı olarak çocuğa yaklaşım birbirinden farklılaşan davranış örüntüleri içerebilmektedir. Diğer bir deyişle, biyolojik temelli olarak çocuğun geçirdiği gelişim evrelerine dayalı evrensel prensipler dışında, her toplum bir bakıma kendi çocuğunu ve çocukluğa ilişkin perspektiflerini oluşturmaktadır. Bu perspektifler içinde çocuğa atfedilen değer ve algılar da aynı toplumun içindeki farklı toplumsal gruplar arasında önemli ölçüde değişiklik gösterebilir.

Çocuğa yönelik farklılaşan bu yaklaşımlar, toplumsal değişimlerin etkilerini anlama ve izlemenin araçlarından biri olarak sosyoloji, sosyal psikoloji ve nüfusbilim disiplinlerinin çalışma konuları arasında yer almaktadır. Türkiye'de Kağıtçıbaşı'nın farklı toplum kesimlerinin çocuğa yönelik ekonomik, sosyal ve psikolojik algıları ve bu algılarda zaman içinde gerçekleşen değişimleri incelediği 'çocuğun değeri' araştırmaları (Kağıtçıbaşı, 1981; Kağıtçıbaşı ve Ataca, 2005, 2017); yine Kağıtçıbaşı’nın (2000; 2017) ailede çocuğa yönelik algı ve beklentilerin kişilik gelişimine etkileri ele 
aldığı çalışmaları; Fişek (2005) tarafından gerçekleştirilen 'geleneksel/kır kökenli' ve 'modern/kent kökenli' aile tipolojileri ikiliğinde aile ve ergen ilişkilerini ele aldığ 1 çalışma; Yavuz ve Özmete'nin (2012) ebeveynler ve 18-25 yaş arası çocukları arasındaki ilişkileri iki taraf açısından inceledikleri çalışma; Zeybek (2013) tarafından gerçekleştirilen toplumda değişen anne ve baba rollerinin çocukla ilişki biçimini ve çocuğa atfedilen değerleri de dönüştürdüğünü öne sürdüğü çalışma; Topçu'nun (2018) Ankara'da yaşayan farklı sosyo-ekonomik ve kültürel gruplardan erkeklerin babalık ve çocuk sahibi olma hakkındaki algıları üzerine çalışması; Beşpınar ve Beşpınar'ın (2018) dindar ve seküler kimliklerin babalık deneyimleri ve çocuk hakkındaki düşünceleri üzerindeki etkilerini araştırdıkları çalışma ve Koçkar ve Harma'nın (2018) TAYA 2016 verisinden yıllar içinde çocuğa atfedilen değerin değişimi üzerine gerçekleştirdikleri analiz, Aysan'ın (2018) kuşaklar arası transferleri ele aldığı çalışma bu konuda gerçekleştirilen çalışmalar arasından örnek olarak verilebilir.

Ebeveynlerin çocuk sahibi olma hakkındaki algıları ve çocuklara ilişkin atfettikleri değerlere ilişkin öncü çalışmaları gerçekleştiren Kağıtçıbaşı'nın (1981; 2017) araştırmalarında çocuğa atfedilen sosyal, psikolojik ve ekonomik değer olmak üzere üç farklı değer türü tanımlanmıştır. Çocuğun ekonomik değeri (maddi fayda, ekonomik fayda) öncelikle eve ekonomik açıdan gelir getirmesi ve katkı yapması, çocuğun ev işleri yapması ve yaşlılıkta ebeveynlerine bakım sağlamasını ifade ederken; Çocuğun psikolojik değeri, çocuğun eve neşe vermesi, duygusal açıdan doyum sağlaması ve anne-babaları birbirine yaklaştırması olarak düşünülmektedir. Son olarak, çocuğun sosyal değeri ise; ailenin devamlılı̆̆ını sağlaması, ebeveynlere toplumsal başarı ve itibar algısı vermesi gibi unsurları anlatmaktadır (Kağıtçıbaşı ve Ataca, 2017, s. 78).

Kağıtçıbaşı (2000; 2017) çalışmalarında genellikle kırsal kesimde yaşayan, çok çocuklu, sosyo-ekonomik düzeyi düşük ve eğitim seviyesi düşük aile koşullarında ailenin çocuklardan maddi beklentisinin yüksek olduğunu bulmuştur. Bunun nedeni çocukların maddi katkılarının ve ekonomik faydalarının kırsal kesimlerde yaşayanlar için hayati işlevlere sahip olmasıdır. Sosyo-ekonomik gelişmeyle birlikte ise çocuğun ekonomik değerine ilişkin ailelerin yüklediği anlam değişmekte ve bu değer azalmaktadır. Ebeveynlerin eğitimlerinin artması, değişen yaşam tarzları ve özellikle kentleşme ile birlikte çocuğun çalışması ve aileye ekonomik fayda sağlaması önemini yitirmektedir. Örneğin, lise eğitimi düzeyine kadar olan eğitim kategorinde çocuktan maddi beklenti ebeveynler için büyük önem taşımaktadır. Lise ve özellikle Üniversite ve daha üst düzeyinde eğitime sahip ebeveynlerde ise bu beklenti önemli derecede azalmaktadır. Bu faktörler çocuğun hem daha az çalışması hem de ailenin buna daha az önem vermesiyle kendini göstermektedir (Kağıtçıbaşı, 2000, s. 56; 2017, s. 167). Kağıtçıbaşı bu durumu şu şekilde ifade etmektedir:

Geleneksel (kırsal/düşük SES) bağımlı aile modelinde ebeveynler, maddi ihtiyaçlar ve yaşlılık dönemi güvencesi nedeniyle büyüyen çocuklarına bağımlıdırlar. Bu bağlamda, itaat yönelimli 
çocuk yetiştirme, çocuklara ilişkiselliği ve aileye bağımlılığı telkin etmeyi amaçlar. Özerk bir çocuğun büyüdüğünde ailesinden ziyade kendi gereksinimlerini gözetmesinin olası olduğu ayrı ve özgür bir genç yetişkin olabileceği nedeniyle, bu noktada çocuğun kendi özerkliği istenmez. Ancak kentleşme ve sosyo-ekonomik gelişmeyle birlikte çocukların kazançtan ziyade ekonomik maliyetlere yol açmaları ve ebeveynlerin de yaşlılık güvencesi için alternatif kaynaklara sahip olmaları nedeniyle, maddi bağımlılıklar azalır. Aynı zamanda özerklik, özellikle okuldaki başarı ve uzmanlaşmış istihdama yönelik olarak değişen kentsel yaşam tarzlarına uyarlanabilir hale gelmektedir. Dolayısıyla ilişkisellik hala değerli iken çocuk yetiştirmede özerkliğe daha fazla yer açılmıştır (Kağıtçıbaşı ve Ataca, 2017, s. 80).

Kağıtçıbaşı'nın çalışmalarında kuşaksal farklılıkların ve yaşın da çocuklara yönelik tutum ve atfedilen değerlerde bir değişime yol açabileceği belirtilmiştir. Genel beklenti, zaman içindeki ve toplumsal tabakalar arasındaki farklılıkların, anneler ve büyükanneler arasındaki kuşak farklılıklarına yansıdığg şeklindedir. Örneğin, anne yaşı arttıkça çocukların bir fayda sağladığı, itibarı arttırdığı ve iş/sosyal hayatı olumsuz etkilediği beyan edilmiştir. Ancak, yeni kuşak annelerin çocuğa yükledikleri maddi/faydacil değerin daha düşük; psikolojik çocuğun değerinin daha yüksek; çocuklardan finansal/ maddi yardıma ilişkin beklentilerinin daha düşük; kız çocuk tercihlerinin daha fazla; çocuklar için bağımsızlık/kendine güven isteklerinin daha fazla ve mevcut, istenen ve ideal çocuk sayılarının daha az olduğu bulunmuştur (Kağıtçıbaşı ve Ataca, 2017, s. 82).

Özellikle toplumda annelerin çalışma hayatına girişiyle birlikte anneliğin dönüşümünün babalık rollerinde de güçlü etkiler yarattığını ortaya koyan yeni çalışmalar (Beşpınar ve Beşpınar, 2018; Topçu, 2018; Zeybek, 2013), değişen annelik ve babalık rollerinin çocuklarla ilişki biçimi ve çocuğa atfedilen değerleri de dönüştürdüğünü öne sürmektedir.

Sunar ve Fişek' in (2005) araştırmasına göre, sosyal ve ekonomik değişimi sağlayan sanayileşme ve kentleşmeyle birlikte değişim en fazla kentli ve eğitimli kesimde meydana gelmiştir. Bu ailelerle ebeveynlerin çocuklarla paylaşımları artmasına rağmen, çocuklara karşı ebeveyn tarafından güçlü bir bakım hiyerarşisinin sürdüğü, çocuğun bireysel yaşantısının ve başarısının önemli olmasıyla birlikte maddi beklentinin azaldı̆̆ı; ancak manevi yakınlık beklentisinin gücünden bir şey kaybetmediği ve duygusal karşılıklılık ya da bağımlılığın önemini ortaya koymaktadır. Benzer şekilde, Aysan'ın (2018) TAYA araştırmasına dayalı istatistiksel analizlerinin işaret ettiği üzere, son on yıl içinde nesiller arası ekonomik transferlerin geçmişe oranla azalmış olması ailenin çocuklardan maddi beklentilerinin azalması bulgusuyla da örtüşmektedir.

Örneğin Topçu (2018, s. 79, 85) farklı sınıflardan (beyaz yakalı ve mavi yakalı) babalarla yaptığı görüşmelere dayanarak, babaların eğitim ve ekonomik sermayelerindeki artışla birlikte, çocuklarının günlük hayatlarındaki ayrıntılara daha fazla hâkim olduğunu ifade etmiştir. Ayrıca bu babalarda çocuklara atfedilen değerlerin farklılaştığını, ev işlerine ve çocuklara bakım ve sorumluluk konularında daha katılımcı olduklarını 
tespit etmiştir. Bu gruptaki babalar, çocuklarının bakımı ve çocuklarının hayatlarındaki pek çok konuyla ilgilenme açısından eşleriyle, daha alt gelir grup babalara nazaran en çok birlikte emek vermeye çalışan baba grubu olarak öne çıkmaktadır. Bu durumu farklı bir şekilde söylersek, kadın istihdamı arttıkça, çocukların bakımı ve ev işlerine katılım konusunda çocukların değil, babaların katkıları artış göstermektedir.

Alanyazında, seküler değerler ile ebeveynlik rol ve pratikleri arasındaki ilişkiye dair çalışmalar oldukça sınırlı olmakla birlikte aile ve çocuk ilişkisinde muhafazakârlık ve dindarlık değerlerinin çok etkili olduğunu öne süren yaklaşımlar söz konusudur (Inglehart ve Baker, 2000). Sekülerleşme genel anlamıyla geleneksel ve dini değerlerden uzaklaşma olarak ifade edilmektedir. Sekülerleşme aynı zamanda bireyin özerkleşmesi ve bireyselci değerleri benimsemesi olarak anlaşıldığ 1 için sekülerlik perspektifi bu bakımdan bireyi bir grubun içinde tanımlayan geleneksel ve muhafazakar anlayıştan bir kopuş olarak da değerlendirilmektedir (Rossi, 2011'den akt., Beşpınar ve Beşpınar, 2018, s. 13-14). İlk bakışta, muhafazakâr değerleri benimsemenin aile ve akraba ilişkilerini öne çıkardığı, seküler değerleri benimsemenin ise bireyi öne çıkardığını söylenebilir. Bu yönüyle, ebeveynlerin dindar ve muhafazakâr veya seküler değerleri benimsemiş olmalarıyla çocuğa atfettikleri değer ve çocuklarla ilişkilerinde önemli farklılıklar olması beklenebilir. Örneğin, Inglehart ve Baker'ın (2000) ifadesiyle, muhafazakâr çocuklarına itaat etmeyi ve dini değerleri aşılarken, seküler değerlere sahip olanların ise çocuklarına bağımsız olma ve kararlı olma gibi davranış kalıplarını tercih etmektedir.

Beşpınar ve Beşpınar'ın (2018) çalışması sosyo-ekonomik düzey olarak orta-üst sınıf kabul edilen ailelerde dindar-muhafazakâr veya seküler değerlere bağlı olarak babaların çocukları ile kurdukları ilişkilerin farklılaştığını öne sürmektedir. Bu araştırma 2013-2015 y1lları arasında Ankara ve İstanbul'da niteliksel araştırma yöntemiyle 30 katılımcı ile gerçekleştirilmiştir. Çalışmada, dine ve geleneğe ağırlık veren ailelerde çocuklara aktarılmaya çalıştıkları değerler arasında "babaya itaat" ve "geleneksel değerler çerçevesinde yaşama" değerlerinin daha baskın olduğu saptanmıştır. Kendisini seküler kimlik ile ifade eden ailelerde ise babalar daha çok "rasyonel kıstaslar çerçevesinde yaşamı algılama" ve "kendini ifade etme" ile ilgili değerleri ön plana çıkardıklarını söylemişlerdir. Buradan hareketle bu iki baba tipolojilerinin çocuktan beklentilerin de farklılaşacağı değerlendirmesi yapılabilir.

Y1llar içerisinde çocuğa verilen değerin incelendiği '2016 Türkiye Aile Yapısı Araştırmasının İleri İstatistikleri’ çalışmasında (Koçkar ve Harma, 2018, s.166) 2006 ve 2016 yılları arasında annelerin çocukları nasıl gördüğü, onlara nasıl bir anlam atfettiği ve atfedilen bu anlamın değişme durumunu incelenmiştir. On yıllık süre içerisinde çocuğun 'maddi bir fayda sağladığı', 'kadının itibarı olumlu etkilediği' inancında tutarlı azalmalar görülmüştür. Benzer şekilde anneler çocuk sahibi olmanın 
'annenin sosyal/ eğitim/ iş hayatını olumsuz etkilediği' düşüncesine daha az oranda katılmışlardır. Özellikle genç kuşaklar anneler arasında çocuğun değerine ilişkin algılama daha önceki kuşaklardan farklılaşmaktadır; çocuktan maddi fayda ve itibar beklentisi düşmekte, çocuğun annenin iş ve sosyal hayatını olumsuz etkilediği düşüncesi daha düşük oranda dile getirilmektedir.

2006 yılında ilki, 2011 yılında ikincisi ve 2016 yılında da üçüncüsü gerçekleştirilen 'Türkiye Aile Yapısı' araştırmalarında katılımcılara 'çocuk, büyüdüğünde annebabasına maddi katkı sağlamalıdır' ifadesine ilişkin düşünceleri sorulmuştur. TAYA 2006'da araştırmaya 18 yaş ve üzeri bireyler katılmıştır. Bu araştırmada soruya verilen yanıtlar sınıflayıcı (nominal) ölçek düzeyinde 'evet' $(\% 76,6)$ ve 'hayır' $(20,5)$ şeklinde kodlanarak alınmıştır (ASPB, 2014a). TAYA 2011'de araştırmaya yine 18 yaş ve üzeri bireylerin katılmıştır. Soruya verilen yanıtlar ise bu kez sıralayıcı (ordinal) ölçek düzeyinde 'katılıyorum $(\% 74,2)$ ', 'kararsızım $(\% 13,3)$ ' ve 'katılmıyorum $(\% 12,6)$ ' şeklinde kodlanarak alınmıştır (ASPB, 2014b). TAYA 2016'da ise diğerlerinden farklı olarak araştırmada 15 yaş ve üzeri katılımcılar yer almıştır. Bu araştırmada soruya verilen yanıtlar 5'li likert ölçeğinde, sıralayıcı ölçme düzeyinde kodlanmıştır. Soruya verilen yanıtlar 'kısmen katılıyorum, katılıyorum ve kesinlikle katılıyorum' kategorilerinde birleştirilmesi ile Türkiye İstatistik Kurumu tarafından yayımlanmıştır. Bu cevapları veren katılımcıların oran1 \%83'tür (TÜIK, 2016a).

\section{Çalışmanın Amacı}

Bu çalışmanın amacı; Türkiye'de ebeveynlerin çocuklardan yana 'ekonomik beklentilerini' güncel verilere dayanarak analiz etmek ve değerlendirmektir. $\mathrm{Bu}$ değerlendirmenin ailelerdeki güncel anne-baba ve çocuklar arasındaki ilişkilerin belirli boyutlarının daha iyi anlaşılmasına katkı vereceği düşünülmektedir.

Çalışmanın kuramsal arka planı, giriş bölümünde kısaca özetlediğimiz çalışmaların bulgularına dayanmaktadır. Bu çalışmalara göre esasen ailelerde çocuğa ilişkin ekonomik, sosyal ve psikolojik üç farklı değer türü atfedilmektedir. Bu kavramsallaştırma çerçevesinde hazırlanan ve Kağıtçıbaşı tarafından 1980 ve 2000'li yıllarda gerçekleştirilen iki farklı araştırma; Türkiye'de zaman içinde çocuktan ekonomik ve sosyal değer beklentisinin azalırken, psikolojik beklentilerin arttığı sonucuna varmıştır. Diğer bir deyişle, bulgular Türkiye'deki sosyo-ekonomik ve kültürel koşulların iyileşmesiyle birlikte ailelerde çocuğun aileye olan ekonomik/maddi katkısından ziyade, çocuğun kendi başına bir değer olarak benimsenmeye başlandığına işaret etmektedir. Bizim çalışmamız da günümüz Türkiye'sini temsil eden TAYA 2016 mikro veri setini kullanarak çocuktan 'ekonomik/maddi beklenti' ile ilgili olan bölümü incelemektedir. Böylelikle farklı sosyo-ekonomik ve kültürel koşullardaki bireylerin çocuğa ilişkin algılarının ne yönde şekillendiğinin çalışıldığı alandaki bilgi birikimine katkı verilmesi amaçlamaktadır. 
Çalışma esas olarak Türk toplumunda uzun yıllardır yaşanan ekonomik, kültürel ve sosyal değişimlerin bağlamını dikkate alarak; bireylerin demografik, sosyoekonomik, kültürel ve yerleşim yeri özelliklerinin çocuğun ekonomik değerine/maddi faydasına atfettikleri anlamları önemli ölçüde belirlediği varsayımına dayanmaktadır. Bu yaklaşım uyarınca; çalışmamızda, daha genç kuşaklardan olan, daha yüksek sosyoekonomik statü ve eğitime sahip, daha seküler tutumları benimsemiş, kent sosyal ortamında daha uzun süredir yaşayan bireylerin çocuklarından maddi/ekonomik katkı beklenti düzeyinin daha ileri yaşlarda olan, daha düşük sosyo-ekonomik statüye ve eğitime sahip, daha dindar tutumları benimsemiş ve daha kırsal özellikteki yerleşim yerlerinde yaşayan bireylerden anlamlı derecede düşük olacağı öne sürülmektedir.

\section{Yöntem}

\section{Veri}

$\mathrm{Bu}$ çalışmadaki veri analizinde, Türkiye İstatistik Kurumu ve Aile ve Sosyal Politikalar Bakanlığ ${ }^{4}$ tarafından 1 Haziran-26 Eylül 2016 tarihlerinde gerçekleştirilen “2016 Türkiye Aile Yapısı Araştırması (TAYA 2016b)’nın mikro verisi kullanılmıştır. TAYA-2016'nın örneklemi 2 aşamalı, tabakalı, küme örneklemidir. Örneklem olasılıklı olarak seçilen 17239 haneden oluşmaktadır. Araştırmanın örneklemi Türkiye geneli, İstatistiki Bölge Birim Sınıflaması (İBBS) Düzey 1 (12 coğrafi bölge) ve üç büyük il (İstanbul, İzmir Ankara) bazında tahmin verebilecek şekilde olarak tasarlanmıştır.

Araştırmada, görüşme geçekleştirilen hanehalklarındaki 15 ve yukarı yaştaki erkek ve kadın 35475 bireye soru formu uygulanmıştır. TAYA-2016'da 'Hanehalkı Soru Formu' ve 'Birey Soru Formu' şeklinde iki soru formu kullanılmıştır. Bu formlarda yöneltilen sorularla birlikte bireylerin; cinsiyet, yaş, eğitim durumu, çalışma durumu, evlenme, çocuk bilgileri gibi özellikleri, üyesi oldukları hanehalkının gelir grubu, yaşadıkları konutun özellikleri, aile ortamındaki yaşam biçimlerini ve aile hayatına ilişkin değer yargılarının analiz edilmesini sağlayacak mikro veriler elde edilmiştir (TÜİK, 2016b).

Bu çalışmada hem Hanehalkı hem de Birey Soru Formundan elde edilen veriler kullanılmıştır. Çok değişkenli analizde analiz birimini, öz veya üvey en az bir çocuk sahibi olan bireyler oluşturmaktadır.

410 Temmuz 2018 tarihli ve 30474 sayılı Resmi Gazete yayımlanan Cumhurbaşkanlığı Kararnamesi ile Çalışma Bakanlığı ile birleştirilerek “T.C. Aile, Çalışma ve Sosyal Hizmetler Bakanlığı” ismini almıştır.

5 TÜİK tarafından gerçekleştirilen sayım ve araştırmalara mikro verilerine erişim olanağı sağlanmaktadır. Mikro veri kullanım koşullarına TÜİK'nun web sitesinden Bilgi Talebi/Mikro Veri Kullanımı bölümünden erişillebilir. 


\section{Araştırma Modeli}

$\mathrm{Bu}$ çalışmanın veri analizi bölümü korelasyonel araştırma özelliğindedir. Bu tip araştırmalar, bir durumun iki veya daha fazla boyutu arasındaki ilişki veya karşıllklı bağımlılığın keşfedilmesi ve incelenmesine yönelik araştırmalardır (Kumar, 2011).

\section{Analiz Metodu}

Bireylerin çocuklarından ekonomik beklentileriyle ilgili düşüncelerini etkileyen faktörler incelenirken İsimsel Lojistik Regresyon modeli kullanılmıştır. Bu model, sınıflama (nominal) düzeyde ölçülen bir bağımlı değişkenin ikiden fazla kategoriye sahip olduğu durumlarda kullanılan, (ikili) lojistik regresyon modelinin bir uzantısıdır. (Retherford ve Choe, 1993; Chan, 2005). Model, siralayıc1 lojistik regresyon modelinin yeteri kadar iyi sonuç vermediği durumlarda, sıralayıcı (ordinal) düzeyde ölçülen bağımlı değişkenler için de kullanılabilmektedir (Laerd Statistics, 2018).

Modelin analiz sonuçları, bağımsız değişkenin bağımlı değişkenin sonucuna etkisinin olup olmadığını, eğer etki varsa, bu etkinin boyutunu gösterir (National Centre for Research Methods, 2011). Bağımlı değişkende, gözlemler birbirinden bağımsız olmalı, kategoriler ise karşılıklı olarak birbirini dışlayan ve kapsayıcı nitelikte olmalıdır. Bu yöntemde gerek kategorik gerekse sürekli değişkenler modelde bağımsız (açıklayıcı) değişken olarak yer alabilir. Bağımsız kategorik değişkenlerin bir kategorisi karşılaştırma amacıyla referans kategorisi olarak seçilirken her bir kategori için katsayılar hesaplanmaktadır. Modelde yer alacak olan bağımsız değişkenler arasında çoklu doğrusal bağlantı/çoklu eş-doğrusallık (multicollinearity) olmamasına dikkat edilmelidir.

İsimsel lojistik regresyon modeli analiz sonucunda standardize edilmiş ( $\beta$ ) katsayı değerleri elde edilir. Bu katsayılar bağımlı değişkenin bağımsız değişken kategorilerdeki değişimlerden ne miktarda ve ne yönde etkilendiğini göstermektedir. $\operatorname{Exp}(\beta)$ yani Odds Oranları (odds ratio) ise ( $\beta$ ) katsayılarının üstel ifadesi olup model çıktılarını yorumlamakta kolaylık sağlarlar. Odds oranları esasen referans olarak alınan kategori yerine diğer kategorileri tercih etme eğilimini (riskini) gösterir; yani, modellerdeki diğer tüm değişkenler sabit tutulduğunda bağımsız değişkenin referans kategorisi yerine karşıllaştırma yapılan diğerlerini tercih etme eğilimleri ortaya konmaktadır. Yüksek pozitif (negatif) katsayısı olan parametreler, referans kategoriye göre o kategorinin seçilme ihtimalini artırır (azaltır). Benzer şekilde $(\beta)$ katsayıların işaretleri bağımlı değişken ile bağımsız değişken kategorileri arasındaki ilişkinin yönü yönünü; $(+)$ aynı veya (-) ters yönlü, göstermektedir. Pozitif (negatif) yönlü $(\beta)$ katsayılarında Odds oranları 1'den büyük (küçük) olarak hesaplanmaktadır. 


\section{Değişkenler}

Bağımlı değişken. Modelde, "çocuk büyüdüğünde anne babasına maddi katk1 sağlamalıdır”' ifadesine katılanlar ('katılıyorum' veya 'kesinlikle katılıyorum' yanıtları) bağımlı değişkende referans kategorisi olarak belirlenmiştir. 'Katılmıyorum' bağımlı değişkende en sık tercih edilen yanıt kategorisidir (Tablo 1).

Tablo 1

Bağımlı Değişken İçin Betimsel İstatistikler (Öz ya da Üvey En Az Bir Çocuğu Olan Bireyler)

\begin{tabular}{|c|c|c|c|c|c|c|}
\hline & Kategoriler & $\mathbf{N}$ & $\%$ & $\begin{array}{l}\text { Bağımlı } \\
\text { Değişken }\end{array}$ & $\mathbf{N}$ & $\%$ \\
\hline \multirow{5}{*}{$\begin{array}{l}\text { Çocuktan maddi } \\
\text { beklenti ifadesi: } \\
\text { "Çocuk büyüdüğünde } \\
\text { anne babasına maddi } \\
\text { katkı sağlamalıdır" }\end{array}$} & Kesinlikle katılmıyorum & 696 & 2,7 & \multirow{2}{*}{ Katılmiyorum } & \multirow[b]{2}{*}{4693} & \multirow[b]{2}{*}{18,0} \\
\hline & Katılmiyorum & 3997 & 15,4 & & & \\
\hline & Kısmen katıliyorum & 3509 & 13,5 & $\begin{array}{l}\text { Kismen } \\
\text { katılıyorum }\end{array}$ & 3509 & 13,5 \\
\hline & Katıliyorum & 14942 & 57,4 & \multirow{2}{*}{$\begin{array}{l}\text { Katılıyorum } \\
\text { (referans } \\
\text { kategorisi) }\end{array}$} & \multirow{2}{*}{17810} & \multirow{2}{*}{68,5} \\
\hline & Kesinlikle katılıyorum & 2868 & 11,0 & & & \\
\hline & Toplam & 26012 & 100,0 & & 26012 & 100,0 \\
\hline
\end{tabular}

3 kategorisi olan bağımlı değişkene göre yapılan analizde; 'katılıyorum' ifadesi karşısında 'katılmıyorum' ifadesini ve 'katılıyorum' ifadesi karşısında 'kısmen katılıyorum' ifadesini söyleme eğilimlerinin odds oranları hesaplanmaktadır. Analize dâhil ettiğimiz her bir bağımsız değişken ve her birinin kategorileri de söz konusu eğilimlerin gerçekleşmesini etkilemektedir. Dolayısıyla analizde bir bağımsız değişkende referans kategorisi olarak tercih edilen kategoriye göre hesaplanan odds oranları esasen o bağımsız değişkenin, bağımlı değişkende incelenen durumun gerçekleşme olasılığını hangi yönde ve ne kadar etkilediğini gösterir. Bu çalışmadaki modele göre; Odds oranlarının 1'den küçük değerlerde olması, modeldeki diğer tüm bağımsız değişkenlerin etkisi sabit tutulduğunda, incelenen bağımsız değişkenin kategorisinin 'katılıyorum' ifadesi karşısında 'katılmıyorum' ya da 'kısmen katılıyorum' ifadesinin eğilimini azalttığını gösterir. Odds oranının 1'den yüksek değerde olmasında ise incelenen bağımsız değişkenin kategorisinin söz konusu eğilimi arttırdığını gösterir.

6 TAYA araştırmalarına çocuğun algılanması ve değerine ilişkin soruların gözden geçirilmesi, bu konuya ilişkin çalışmaların daha derinlemesine analiz imkânına kavuşarak devam edilmesini sağlayacaktır. 2006, 2011 ve 2016 araştırmalarında aynı soruya verilen cevabın farklı̈ ölçek düzeylerinde kodlanmış olması, araştırmaya esas teşkil eden nüfusun yaş sınırlarının farklı olması araştırmaların bulguları arasında doğrudan doğruya bir karșılaștırma yapma olanağını azaltmaktadır.

Türkiye Aile Yapısı Araştırmalarında kullanılan "Çocuk büyüdüğünde anne babasına maddi katkı sağlamalıdır” ifadesinin ise çocuğun ekonomik değerini temsil etme bakımından tek başına kullanılması esasen ölçmenin 'geçerliliğine' ilişkin bazı sorunları akla getirmektedir. Bu bakımdan yeni bir TAYA uygulamasında çocuğun ekonomik değerine ilişkin ölçmenin iyileştirilmesine yönelik yeni soruların eklenmesi düşünülebilir. Bu kapsamda cevaplayıcının ‘çocuğun büyümesinden' ne anladığının tespit edilmesi önemlidir. Ayrıca, ölçme aracına 'çocuk ne ölçüde maddi fayda sağlamalı?', ya da 'çocuktan ne ölçüde fayda beklenmelidir?', 'hangi durumlarda veya hangi konulara ilişkin çocuktan maddi beklenti anlamlıdır?' vb. gibi ek sorular yer alabilir. 
Bağımsız değişkenler. Çalışmada kullanılan bağımsız değişkenler dört grupta ele alınmıştır; 'demografik', 'sosyo-ekonomik', 'kültürel tutumlar' ve 'yerleşim yeri özellikleri'. Bağımsız değişkenlerin her birinde son kategori o değişken için referans (karşılaştırma) kategorisi olacak şekilde düzenlenmiştir.

Demografik değişkenler; "Cinsiyet", "Yaş" ve "Çocuk sayısı" kategorik değişkenler olup kategorileri aşağıdaki gibidir:

Cinsiyet: 1 'Kadın' ve 2 'Erkek' (referans kategorisi)

Yaş: 1 '15-29', 2 '30-39', 3 '40-49' ve 4 '50 yaş veya üzeri' (referans kategorisi)

Çocuk sayısı: 1 'Tek çocuk', 2 '2 çocuk', 3 '3 çocuk' ve '4 veya üzeri çocuk' (referans kategorisi)

Sosyo-ekonomik değişkenler; cevaplayıcının 'tamamlanan eğitim düzeyini' gösteren bir kategorik değişken ile başlangıçta sürekli bir değişken olarak hazırlanıp daha sonra kategorilere ayrılan 'hanehalkı refah düzeyi' değişkenidir. Bu değişkenlerin kategorileri aşağıdaki gibidir:

Tamamlanan eğitim düzeyi: 1 'Üniversite veya üzeri', 2 'Lise', 3 ‘'̇lkokul-illköğretimOrtaokul' ve 4 'Bir okul bitirmedi' (referans kategorisi)

Hanehalkı refah düzeyi: 1 'En yüksek', 2 'Yüksek', 3 'Üst orta', 4 'Alt orta', 5 'Düşük' ve 6 'En düşük' (referans kategorisi)

TAYA-2016' da hanelere giren gelir ve bireylerin kişisel gelirleri hakkında veri toplanmıştır. Bununla birlikte bu veri kendi başına hanehalklarının refah durumunu tam olarak temsil edebilmek için yeterli değildir. Hanehalklarının sosyo-ekonomik durumunu daha iyi anlayabilmek için gelir verisi yanı sıra örneğin tüketim verisi gibi başka verilere de ihtiyaç vardır. Ayrıca hanehalkı araştırmalarında tam ve doğru şekilde gelir verisi toplayabilmek için cevaplayıcılara çok sayıda soru sorulması gerekir ki TAYA-2016'da bu konuyla ilgili özel bir modül bulunmamaktadır .

Bu koşullar altında, hanehalkının refah düzeyini temsil etmek üzere aracı (proxy) değişken oluşturulması yoluna gidilebilir. Araştırmada kullanılan soru formlarından üretilen mikro verilerde bir hanehalkının sosyo-ekonomik durumuyla doğrudan veya dolaylı olarak ilgili olduğunu düşündüğümüz çok sayıda ve farklı özellikte değişken bulunmaktadır. $\mathrm{Bu}$ değişkenlerin endeks kurma yaklaşımlarıyla toplulaştırılması ve böylelikle hanehalkının sosyo-ekonomik refah durumunu yansıtacak bir nihai değişkenin oluşturulmasını sağlayan yöntemler bulunmaktadır (Rutstein ve Johnson,

7 Araştırmada cevaplayıcılara farklı gelir kalemlerinden (yevmiye, tarım dışı, tarım, kira vb.) gelir elde edip etmedikleri sorulmuş ve ardından "Gelir kaynaklarınızdan elde ettiğiniz toplam aylık ortalama net geliriniz ne kadardır?" sorusu yöneltilmiştir. Dolayısıyla ile gelir hakkında niceliksel veri esasen sadece bir tek değişkenle toplanmıştır. 
2004; Vyas ve Kumaranayake, 2006). Bu yöntemlerde öncelikle farkl1 ölçek türlerinde toplanmış veriler standartlaştırılarak Temel Bileşenler Analizi (Principal Component Analysis) uygulanmaktadır. Böylelikle değişkenlerin bileşke etkisini yansıtan faktör skorları hesaplanmaktadır. Endeks oluşturmada kullanılan her bir madde bu faktör skor değerleri ile ağırlıklandırılmaktadır. Elde edilen değerler sıfır ortalama ve bir standart sapma ile standartlaştırılmakta ve her bir hanehalkı için bu değerler toplanmaktadır. Son olarak hanehalkı üyeleri yaşadıkları hanehalkının toplam skoruna göre sıralanmakta ve bu nüfus her birisinde aynı sayıda kişiyi içeren gruplara ayrıştırılmaktadır (HÜNEE, 2014).

Çalışmamızda, TAYA-2016'nın 'hanehalkı', 'fert' ve 'fertliste' mikro verileri incelenerek söz konusu endeks oluşturma yönteminde kullanılabilecek alternatif değişkenler tespit edilmiştir. Bu değişkenlerin modellerde uygunluğunun denenmesi neticesinde; her bir hane için hesaplanan 'kişi başı ortalama gelir8', 'kişi başı ortalama eğitim puanı' ile 'hanedeki dayanıklı tüketim mallarının' kullanılmasıyla bir endeks kurulmasına karar verilmiştir. Böylelikle hanehalkının hem gelirini hem sosyal statüsünü hem de tüketimini yansıtacak bir bileşke değişken elde edilmiştir. Son aşamada elde edilen puanlar yüzde 5'lik 20 gruba bölünerek en düşükten en yükseğe doğru sıralanmıştır. Bu grupların 6 farklı kategoride sınıflandırılması ile analizlerde kullanılacak olan hanehalkı refah düzeyi değişkenine son hali verilmiştir. Bu değişkende kategoriler en yüksek yüzdelik dilimden en düşüğe doğru şu şekilde oluşturulmuştur: 'En yüksek' (90.0-100.0), 'Yüksek' (75.0-89.9), 'Üst orta' (50.0-74.9), 'Alt orta' (25.049.9), 'Düşük' (10.0-24.9) ve ‘En düşük' (0.0-9.9).

Kültürel tutum değişkenleri; 'tek çocuk için cinsiyet tercihi', 'dini inancin yaşam üzerinde etkisi' ve 'tolerans düzeyi’ değişkenleridir.

Tek çocuk için cinsiyet tercihi: Cevaplayıcılara 'Tek çocuk sahibi olsaydınız, çocuğunuzun cinsiyeti ne olsun isterdiniz?’ sorusu yöneltilmiştir. Bu değişkenin cevap kategorileri; 1 'Kız', 2 ‘Erkek’ ve 3 'Farketmez' (referans kategorisi) şeklindedir.

Dini inancın yaşam üzerinde etkisi: Aşağıda detayları açıklanan işlemlerden sonra elde edilen oranlı (ratio) ölçek düzeyindeki değişken, analizde anlamayı kolaylaştırması bakımından 1 'Etkili değil', 2 'Düşük düzeyde etkili', 3 'Orta düzeyde etkili', 4 'Yüksek düzeyde etkili’ (referans kategorisi) kategorilerine kodlanmıştır.

Tolerans Düzeyi: Bir önceki değişkenle aynı yöntem kullanılarak elde edilen oranlı (ratio) ölçek düzeyindeki değişken 1 'Tolerans var', 2 'Kısmi tolerans var' ve 3 'Tolerans yok' (referans kategorisi) şeklinde kategorilere ayrışmıştır.

8 Hanehalkının sosyo-ekonomik statüsünün belirlenmesinde 'Kişi başı ortalama gelir' ve 'kişi başı ortalama eğitim puanı’ değişkenlerinin kullanımı için bakınız (Kalaycıŏlu vd., 2010). 
TAYA 2016'da cevaplayıcıların Dini inancın yaşam üzerindeki etkisini anlamak üzere "Dini inanç .... ne 'kadar belirleyicidir?" soru kalıbıla cevaplayıcıya 'eş seçiminde', 'arkadaş seçiminde', 'iş seçiminde', 'yaşanacak çevre seçiminde', 'çocukların eğitiminde', 'kılık/kıyafet seçiminde', 'yiyecek/içecek seçiminde', 'komşuluk ilişkilerinde' ve 'oy vermede' şeklinde 9 soru yöneltilmiştir. Soruların cevap kategorileri 1 'Hiç belirleyici değil', 2 'Belirleyici değil', 3 'Orta', 4 'Belirleyici' ve 5 'Çok belirleyici' şeklinde 5'li Likert ölçeği ile kodlanmıştır. Kadın ve erkek birlikteliğine ilişkin tolerans ile ilgili olarak da TAYA 2016'da cevaplayıcılara önce ‘... ifadeye ne ölçüde katıldığınızı belirtiniz?' sorusu yöneltmiş ve ardından şu ifadeler okunmuştur; 'Çiftler nikahsız (resmi veya dini) olarak birlikte yaşayabilir', 'Erkek, farklı din ve milliyetten biri ile evlenebilir', 'Kadın, farklı din ve milliyetten biri ile evlenebilir', 'Çiftler, evlilik dışı çocuk sahibi olabilir', 'İnternette tanışılan birisiyle evlilik yapılabilir' ve 'Farklı mezhepten kişiler birbiriyle evlenebilir'. Bu ifadelere verilen yanitlar da 1 'Kesinlikle katılmıyorum', 2 'Katılmıyorum', 3 'Kısmen katılıyorum', 4 ‘Katılıyorum' ve 5 'Kesinlikle katılıyorum' şeklinde 5'li Likert ölçeği ile kodlanmıştır.

Dini inancın yaşam üzerindeki etkisi ve tolerans düzeyine ilişkin sorular esasen cevaplayıcıların dini inanç ve yaşam tarzları hakkındaki düşüncelerinin bireysel ve sosyal yaşantılarındaki bazı davranışlarına ve tercihlerine olan etkilerini anlamaya yönelik olan "tutum" sorularıdır. Dolayısıyla bu sorulara verilen yanıtlar bir ölçek yaklaşımı ile değerlendirilip nihai bir gösterge değişkenine dönüştürülebilir. Bu durumda öncelikle söz konusu ölçeğin toplanabilme özelliğinin olması gerekir. Bu durumun tespitine yönelik maddeler arası negatif korelasyon olup olmadığını anlamak üzere 'güvenirlik analizi' gerçekleştirilmelidir (Bayram, 2004).

Dini inancın yaşam üzerine etkisine yönelik sorular ile güvenirlik analizi gerçekleştirildiğinde, güvenirlik katsayısı olan Cronbach Alpha 0,93 olarak bulunmuştur. Tolerans düzeyine yönelik soruların güvenirlik analizinde kullanılan ölçek için ise Cronbach Alpha değeri 0,81'dir. Bu iki ölçekte de hiçbir değişken toplam korelasyon ile negatif ilişki içinde değildir. Aynı zamanda değişkenler arası toplam korelasyon değerleri yüksek düzeyde çıkmıştır. Ölçeğin güvenirlik değerlendirmesinde Cronbach Alpha katsayılarının $0,90 \leq \alpha \leq 1,00$ aralığında olması da maddelerin yüksek düzeyde bir güvenirliğe sahip olduğuna işaret etmektedir (Can, 2014).

Tablo 2

Ölçek Değişkenler İçin Betimsel İstatistikler

\begin{tabular}{|l|c|c|}
\hline & $\begin{array}{c}\text { Dini inancin yaşam } \\
\text { pratiklerindeki etkisi }\end{array}$ & Tolerans Düzeyi \\
\hline Ortalama & 3,55 & 2,10 \\
\hline Std. Sapma & 0,85 & 0,70 \\
\hline Mininum değer & 1 & 1 \\
\hline Maksimum değer & 5 & 5 \\
\hline
\end{tabular}


Maddelerin ortalama değerlerini toplamak suretiyle oluşturduğumuz ölçek değişkenlerin betimsel istatistikleri Tablo 2'de sunulmaktadır. Ölçek değişkenlerdeki ortalama değerlerin dağılımları ve ölçeği oluşturan soruların cevap kodlarındaki sınıflama dikkate alınmış ve aşağıdaki kıstas uyarınca oranlı (ratio) düzeydeki değişkenler kategorik değişkenlere dönüştürülmüsşür:

Dini inancın yaşam pratiklerindeki etkisi: 1,00-2,00: 'Etkili değil', 2,01-3,00: 'Düşük düzeyde etkili', 3,01- 4,00: 'Orta düzeyde etkili', 4,01-5,00: 'Yüksek düzeyde etkili'

Tolerans Düzeyi: 1,00-2,00: 'Tolerans yok', 2,17-3,00: 'Kısmi tolerans var', 3,175,00: 'Tolerans var'

Yerleşim yeri değişkenleri; '15 yaşına değin yaşanan yerleşim yeri' ve 'İBBS-12 düzeyi’ değişkenleridir.

15 yaşına değin yaşanan yerleşim yeri: Cevaplayıcılara yöneltilen "aşağıdaki yerleşim yerlerinden hangisi, sizin 15 yaşına kadar en uzun süre yaşadığınız yerleşim yerini en iyi ifade eder?" sorusunun yanıtından elde edilmiştir. Değişkenin kategorileri şu şekildedir; 1 'İl merkezi', 2 'İlçe merkezi', 3 'Yurt dışı' ve 4 'Bucak veya köy' (referans kategorisi).

İBBS-12: Araştırmanın gerçekleştirildiği tarihte cevaplayıcının bulunduğu İstatistiki Bölge Birimi Sınıflamasını (1. Düzey) göstermektedir. Bu değişkenin 12 kategorisi bulunmaktadır; 1 'İstanbul', 2 'Batı Marmara', 3 'Ege', 4 'Doğu Marmara', 5 'Bat1 Anadolu', 6 ‘Akdeniz', 7 'Orta Anadolu', 8 ‘Batı Karadeniz', 9 'Doğu Karadeniz', 10 'Kuzeydoğu Anadolu', 11 'Ortadoğu Anadolu' ve 12 'Güneydoğu Anadolu' (referans kategorisi).

\section{Çoklu Bağlantılılık Kontrolü}

Çoklu bağlantılı olma durumu regresyon analizine sokulan bağımsız değişkenler arasında çok yüksek düzeyde ilişki olması ( $\mathrm{r} \geq 0,9)$ anlamına gelir (Can, 2014). Bu inceleme için öncelikle bağımsız değişkenler arasındaki basit doğrusal korelasyon katsayıları kontrol edilmiştir. Bu katsayılar çok yüksek düzeyde değildir. Daha sonra hoşgörü (Tolerance) katsayılarının çok düşük ( 0,1 'den küçük) ve VIF değerlerinin de çok yüksek olmadığ 1 (en yüksek 2,36) görülmüsştür. Dolayısıyla analize dâhil ettiğgimiz değişkenler arasında çoklu bağlantı oluşturan değerlere rastlanmamıştır.

\section{Betimsel İstatistikler}

Çalışmanın gerçekleştirildiği örneklem ile ilgili betimsel istatistikler Tablo 3 'te verilmiştir. 
Tablo 3

Bağımsız Değişkenler için Betimsel İstatistikler

\begin{tabular}{|c|c|c|c|c|}
\hline & Bağımsız Değișken & Kategoriler & $\mathbf{N}^{*}$ & $\% * *$ \\
\hline \multirow{10}{*}{$\begin{array}{l}\text { Demografik } \\
\text { değişkenler }\end{array}$} & \multirow{2}{*}{ Cinsiyet } & Kadın & 14949 & 57,5 \\
\hline & & Erkek (ref.) & 11063 & 42,5 \\
\hline & \multirow{4}{*}{ Yaş } & -29 & 2005 & 7,7 \\
\hline & & $30-39$ & 5925 & 22,8 \\
\hline & & $40-49$ & 5994 & 23,0 \\
\hline & & $50+($ ref. $)$ & 12088 & 46,5 \\
\hline & \multirow{4}{*}{ Çocuk sayısı } & Tek çocuk & 4021 & 15,4 \\
\hline & & 2 çocuk & 9141 & 35,2 \\
\hline & & 3 çocuk & 6248 & 24,0 \\
\hline & & 4 veya daha fazla çocuk (ref.) & 6602 & 25,4 \\
\hline \multirow{10}{*}{$\begin{array}{l}\text { Sosyo-ekonomik } \\
\text { değişkenler }\end{array}$} & \multirow{4}{*}{$\begin{array}{l}\text { Tamamlanan eğitim } \\
\text { düzeyi }\end{array}$} & Üniversite veya üzeri & 3262 & 12,5 \\
\hline & & Lise & 3613 & 13,9 \\
\hline & & İlkokul-Ortaokul-İlköğretim & 14349 & 55,2 \\
\hline & & Bir okul bitirmedi (ref.) & 4788 & 18,4 \\
\hline & \multirow{6}{*}{ Hanehalk1 refah düzeyi } & En Yüksek & 2535 & 9,8 \\
\hline & & Yüksek & 3792 & 14,6 \\
\hline & & Üst Orta & 6019 & 23,1 \\
\hline & & Alt Orta & 6499 & 25,0 \\
\hline & & Düşük & 3955 & 15,2 \\
\hline & & En düşük (ref.) & 3212 & 12,3 \\
\hline \multirow{10}{*}{$\begin{array}{l}\text { Kültürel tutum } \\
\text { değişkenleri }\end{array}$} & \multirow{3}{*}{$\begin{array}{l}\text { Tek çocuk için cinsiyet } \\
\text { tercihi }\end{array}$} & $\mathrm{K}_{1 \mathrm{z}}$ & 4483 & 17,2 \\
\hline & & Erkek & 3592 & 13,8 \\
\hline & & Fark etmez (ref.) & 17937 & 69,0 \\
\hline & \multirow{4}{*}{$\begin{array}{l}\text { Dini inancın yaşam } \\
\text { pratiklerindeki etkisi }\end{array}$} & Etkili değil & 1778 & 6,8 \\
\hline & & Düşük düzeyde etkili & 5151 & 19,8 \\
\hline & & Orta düzeyde etkili & 14069 & 54,1 \\
\hline & & Yüksek düzeyde etkili (ref.) & 5014 & 19,3 \\
\hline & \multirow{3}{*}{ Tolerans düzeyi } & Tolerans var & 1888 & 7,3 \\
\hline & & Kismi tolerans var & 9451 & 36,3 \\
\hline & & Tolerans yok (ref.) & 14673 & 56,4 \\
\hline \multirow{17}{*}{$\begin{array}{l}\text { Yerleşim yeri } \\
\text { değişkenleri }\end{array}$} & \multirow{4}{*}{$\begin{array}{l}15 \text { yaşına değin yaşanan } \\
\text { yerleşim yeri }\end{array}$} & İl merkezi & 7501 & 28,8 \\
\hline & & İlçe merkezi & 6348 & 24,4 \\
\hline & & Yurt diş1 & 434 & 1,7 \\
\hline & & Bucak veya köy (ref.) & 11729 & 45,1 \\
\hline & \multirow{12}{*}{ İBBS-12 } & İstanbul & 3080 & 11,8 \\
\hline & & Batı Marmara & 1711 & 6,6 \\
\hline & & Ege & 3950 & 15,2 \\
\hline & & Doğu Marmara & 2482 & 9,5 \\
\hline & & Batı Anadolu & 3270 & 12,6 \\
\hline & & Akdeniz & 2719 & 10,5 \\
\hline & & Orta Anadolu & 1789 & 6,9 \\
\hline & & Batı Karadeniz & 1846 & 7,1 \\
\hline & & Doğu Karadeniz & 1077 & 4,1 \\
\hline & & Kuzeydoğu Anadolu & 896 & 3,4 \\
\hline & & Ortadoğu Anadolu & 1337 & 5,1 \\
\hline & & Güneydoğu Anadolu (ref.) & 1855 & 7,1 \\
\hline & & & 26012 & 100,0 \\
\hline
\end{tabular}

*Ağırlıksız sayı **Ağırlıksız yüzde 


\section{Bulgular}

Çalışmamızda kurduğumuz modelin uygunluğunu gösteren ölçütler, bağımsız değişkenlerin yer aldığı son modelin sabit modelden (bağımsız değişkeni olmayan model - intercept only) daha iyi performansı olduğunu göstermektedir. Modelin Uygunluğu Ölçütünde, - 2 Log Olabilirlik (-2LL) (-2 Log Likelihood), son model için (34 578) olup sabit modeldeki değerden (39 456) anlamlı derecede $(p<0,001)$ daha düşük düzeydedir. Bu sonuç sabit modele bağımsız değişkenlerin eklenmesinin modeli iyileştirdiğini gösterir. Olabilirlik Oran Testi (Likelihood Ratio Test) de, $x^{2}(72)=4$ $879 p<0,001$ son modelin sabit modelden daha başarılı tahminler sunduğunu göstermektedir. Diğer bir deyişle bağımsız değişkenlerle kurulan model, bağımlı değişkendeki varyasyonun açıklanmasını anlamlı derecede arttırmıştır. Model tarafindan açılanan varyasyon Nagelkerke ölçütüne göre \% 21,0'dır. Model uygunluğunun sinandığı bir diğer test de Ki-Kare Uyum Testi (Goodness-of-Fit) ölçütüdür. Bu ölçüt model ile tahmin edilen yeni değerlerin gözlenen değerlerden anlamlı derecede farkılaşıp farklılaşmadığını gösterir. Kurduğumuz modelde Deviance $\mathrm{x}^{2}(31741)=38$ $270, p>0,05$ olması modelin uyum iyiliği olduğunu gösternektedir (Chan, 2005; Field, 2018).

Modeldeki her bir bağımsız değişken için hesaplanan Olabilirlik Oran Testi (Likelihood Ratio Test) sonuçlarına göre modele dahil edilen tüm bağımsız değişkenler, $\mathrm{p}<0,001$ düzeyinde modele anlamlı düzeyde katkı sağlamaktadır. Bununla birlikte hangi bağımsız değişkenin modele daha fazla katkı yaptı̆̆ını anlayabilmek için model her bir bağımsız değişkenin sırayla modele dahil edildiği (stepwise/forward entry) model kurma yöntemi ile kurulmuştur 9 . Böylelikle her bir değişkenin modele katkısı (sabit modelden azaltılan -2 Log Olabilirlik (-2LL) miktarı) ayrı olarak görülebilmektedir. Esasen model kurulumuyla -2 Log Olabilirlik değerinin düşmesi sabit modelde açıklanamayan bilginin bir bölümünün modele eklenen değişkenlerle açıklandığı yani modelin iyileştiği anlamına gelir (National Center for Research Methods, 2011). Dolayısı ile -2 Log Olabilirlik değerindeki azalmayı en fazla miktarda sağlayan bağımsız değişken modele en fazla katkı yapan değişken olarak değerlendirilebilir.

Buna göre, kurduğumuz modeldeki her bir değişkenin -2 Log Olabilirlik değerindeki azalmasına ne kadarını sağladığına baktı̆̆ımızda sırasıyla; 'Tamamlanan eğitim düzeyi' (\%34,2), 'Çocuk sayıs1' (\%33,5), 'Dini inancın yaşam üzerinde etkisi’ $(\% 10,7)$ ve 'Hanehalk1 refah düzeyi' $(\% 6,8)$ değişkenlerinin olduğu görülmektedir ${ }^{10}$. Modelde yer alan diğer 6 değişken toplam -2 Log Olabilirlik değerindeki azalmasının \%14,8'lik bir kısmını sağlamıştır. Dolayısı ile sırasıyla 'İBBS-12', '15 yaşına değin yaşanan yerleşim yeri', 'yaş’, 'cinsiyet', 'tolerans düzey’ ve ‘tek çocuk için cinsiyet tercihi’

9 İşlem hakkında açıklama için bakınız (IBM Knowledge Centre, 2019).

10 SPSS çıktısındaki her bir adıma ilişkin yer alan test sonuçlarındaki $x^{2}$ değerlerinin kıyaslanmasıyla da değişkenlerin model tahmin kabiliyeti değerlendirilebilir (Field, 2018, s. 1175-1176). 
değişkenlerinin modele olan katkıları diğer değişkenlere nispetle daha düşük düzeyde gerçekleşmiştir.

Modeldeki her bir bağımsız değişkende farklı değer alışların bağımsız değişken üzerine olan etkilerini anlayabilmek için Tablo 4 ve Tablo 5 'te sunulan parametre tahminleri incelenmelidir. Tablodaki her bağımsız değişken için son kategori referans kategorisidir. Modelde herhangi bir değişkenin bağımlı değişken üzerine olan etkisi diğer değişkenlerin etkileri sabit tutularak hesaplanmaktadır. Diğer bir deyişle, cevaplayıcıların inceleme konusu olan bağımsız değişkende farklılaşan değerler alırken diğer tüm bağımsız değişkenlerde aynı değeri aldıkları varsayılmaktadır.

Tablo 4, "Çocuk büyüdüğünde anne babasına maddi katkı sağlamalıdır” ifadesine 'katılıyorum' yerine 'katılmıyorum' deme eğilimine, Tablo 5 'te ise ifadeye 'katıliyorum' yerine 'kısmen katılıyorum' deme eğilimine yönelik tahminler sunulmaktadır.

\section{Demografik değişkenler:}

Cinsiyet: Kadın cevaplayıcıların 'çocuk büyüdüğünde anne babasına maddi katk1 sağlamalıdır' ifadesine 'katılmama' yönündeki eğilimleri, erkek cevaplayıcılardan $\% 26$ oranında daha yüksektir; kadın için odds oranı 1,26 ' dır $\left(\beta=0,23\right.$, Wald $\chi^{2}(1)=$ $33,2, \mathrm{p}=0,00)$.

Cevaplayıcının cinsiyeti, ifadeye 'kısmen katılma' eğiliminde etkili olan bir faktör değildir.

Yaş: Cevaplayıcının yaşı, bağımlı değişkendeki ifadeye 'katılmıyorum' şeklinde cevap verme eğilimine anlamlı derecede etki yapmaktadır. '50 ve üzeri yaş' cevaplayıcıların 'katılmıyorum' eğilimine göre, daha genç yaştaki kuşaklarda 'katılmıyorum' eğilimi anlamlı derecede daha yüksektir. Fakat odds oranları incelendiğinde bu ilişkinin doğrusal olmadığı, ifadeye 'katılmıyorum' eğiliminin en yüksekten en düşüğe doğru; '30-39', ‘- 29' ve '40-49' yaş grubunda olduğu gözlenmektedir. '30-39' yaş grubundakilerin 'katılmama' odds oranı ' 50 ve üzeri yaş' grubundan \%88 daha yüksektir.

Cevaplayıcının bulunduğu yaş grubu, ifadeye 'kısmen katılma' eğiliminde etkili olan bir faktör değildir.

Çocuk sayısı: 'Tek çocuk' ve '2 çocuk' sahibi olan cevaplayıcıların bağımlı değişkendeki ifadeye 'katılmıyorum' demeye ilişkin odds oranları, daha fazla sayıda çocuğu olan cevaplayıcıların odds oranlarından anlamlı derecede yüksektir. Tek çocuğu olanlar için odds oranı $1,49\left(\beta=0,40\right.$, Wald $\left.\chi^{2}(1)=29,2, p=0,00\right)$ ve '2 çocuk' sahibi olanlar için 1,19 ' dur $\left(\beta=0,18\right.$, Wald $\left.\chi^{2}(1)=7,8, p=0,00\right)$. İfadeye 'k1smen katılmama' eğilimi ise cevaplayıcının çocuk sayısı ile negatif yönlü ilişkilidir. Diğer bir deyişle, 
daha az sayıda çocuğu olan cevaplayıcıların ifadeye 'kısmen katılmama' eğilimi daha yüksektir.

\section{Sosyo-ekonomik değişkenler:}

Tamamlanan eğitim düzeyi: 'Üniversite veya üzeri' ve 'lise' mezunu olan cevaplayıcıların 'katılmıyorum' deme eğilimleri daha düşük düzeyde eğitimli olan cevaplayıcılardan anlamlı derecede yüksektir. 'Bir okul bitirmemiş' cevaplayıcılara göre 'üniversite veya üzeri' düzeyde eğitimi tamamlamış cevaplayıcıların ifadeye katılmama odds oranları 2,61 kat daha fazladır $\left(\beta=0,96\right.$, Wald $\left.\chi^{2}(1)=88,2, p=0,00\right)$.

Benzer şekilde, eğitim düzeyi daha yüksek olan cevaplayıcıların ifadeye 'kısmen katılma' eğilimleri anlamlı düzeyde daha yüksetir. Yani, odds oranları; eğitim düzeyi ile 'kısmen katılma' eğilimi arasında pozitif yönlü bir ilişki vardır.

Hanehalkı refah düzeyi: Hanehalkının refah düzeyi ile 'katılmıyorum' ve 'kısmen katılıyorum' deme eğilimleri arasında anlamlı ve pozitif yönlü bir ilişki bulunmaktadır. Yani, hanehalkı refah düzeyi kategorilerindeki artışla birlikte 'katılmıyorum' veya 'k1smen katılıyorum' deme odds oranları da yükselmektedir. En yüksek hanehalk1 refah düzeyindeki cevaplayıcıların ifadeye 'katılmıyorum' deme odds oranı, en düşük hanehalk1 refah düzeyindeki cevaplayıc1lardan $3,5 \mathrm{~kat}\left(\beta=1,26\right.$, Wald $\chi^{2}(1)=118,8$, $\mathrm{p}=0,00)$, 'k1smen kat1liyorum' deme odds oran1 da 2,5 kat $\left(\beta=0,91\right.$, Wald $\chi^{2}(1)=$ $60,5, \mathrm{p}=0,00)$ daha yüksektir. 
Tablo 4

Çocuktan Maddi Katkı Beklentisini Etkileyen Faktörler: 'Katılıyorum’Yerine 'Katılmıyorum'Deme Eğilimine İlişkin Isimsel Lojistik Regresyon Sonuçlar

\begin{tabular}{|c|c|c|c|c|c|c|}
\hline \multirow{2}{*}{\multicolumn{3}{|c|}{\begin{tabular}{|l}
$\begin{array}{l}\text { "Çocuk büyüdüğ̈̈̈nde anne babasına maddi katkı } \\
\text { sağlamalıdır" }\end{array}$ \\
'Katılıyorum' yerine 'Katılmıyorum' eğilimi
\end{tabular}}} & & \multicolumn{3}{|c|}{$\begin{array}{c}\text { Odds oranları } \operatorname{Exp}(\beta) \text { için } \\
\text { Güven Aralıkları }\end{array}$} \\
\hline & & & ( $\beta$ ) (SE) & Alt & O.O. & Üst \\
\hline \multicolumn{3}{|c|}{ Sabit (intercept) } & $-4,00(0,13)^{* * * *}$ & & & \\
\hline \multirow{10}{*}{ 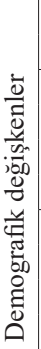 } & \multirow[b]{2}{*}{ Cinsiyet } & Kadın & $0,23(0,04)^{* * *}$ & 1,16 & 1,26 & 1,36 \\
\hline & & Erkek (ref.) & 0,0 & & & \\
\hline & \multirow{4}{*}{ Yaş } & -29 & $0,43(0,08)^{* * *}$ & 1,33 & 1,54 & 1,79 \\
\hline & & $30-39$ & $0,63(0,05)^{* * *}$ & 1,70 & 1,88 & 2,07 \\
\hline & & $40-49$ & $0,31(0,05)^{* * *}$ & 1,24 & 1,36 & 1,50 \\
\hline & & $50+($ ref. $)$ & 0,0 & & & \\
\hline & \multirow{4}{*}{ Çocuk sayısı } & Tek çocuk & $0,40(0,07)^{* * *}$ & 1,29 & 1,49 & 1,72 \\
\hline & & 2 çocuk & $0,18(0,6)^{* *}$ & 1,05 & 1,19 & 1,35 \\
\hline & & 3 çocuk & $0,03(0,6)$ & 0,90 & 1,03 & 1,16 \\
\hline & & 4 veya daha fazla çocuk (ref.) & 0,0 & & & \\
\hline \multirow{10}{*}{ 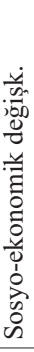 } & \multirow{4}{*}{$\begin{array}{l}\text { Tamamlanan } \\
\text { eğitim düzeyi }\end{array}$} & Üniversite veya üzeri & $0,96(0,10)^{* * *}$ & 2,13 & 2,61 & 3,18 \\
\hline & & Lise & $0,63(0,09)^{* * *}$ & 1,57 & 1,88 & 2,25 \\
\hline & & İlkokul-Ortaokul-İlköğretim & $0,15(0,08)^{*}$ & 1,00 & 1,16 & 1,35 \\
\hline & & Bir okul bitirmedi (ref.) & 0,0 & & & \\
\hline & \multirow{6}{*}{$\begin{array}{l}\text { Hanehalkı refah } \\
\text { düzeyi }\end{array}$} & En Yüksek & $1,26(0,12)^{* * *}$ & 2,81 & 3,52 & 4,42 \\
\hline & & Yüksek & $0,82(0,10)^{* * *}$ & 1,86 & 2,28 & 2,79 \\
\hline & & Üst Orta & $0,55(0,10)^{* * *}$ & 1,44 & 1,74 & 2,10 \\
\hline & & Alt Orta & $0,36(0,09)^{* * *}$ & 1,19 & 1,43 & 1,72 \\
\hline & & Düşük & $0,10(0,10)$ & 0,91 & 1,10 & 1,34 \\
\hline & & En düşük (ref.) & 0,0 & & & \\
\hline \multirow{10}{*}{ 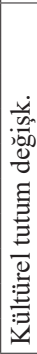 } & \multirow{3}{*}{$\begin{array}{l}\text { Tek çocuk için } \\
\text { cinsiyet tercihi }\end{array}$} & $\mathrm{K} 1 \mathrm{z}$ & $0,13(0,05)^{* *}$ & 1,04 & 1,14 & 1,25 \\
\hline & & Erkek & $0,00(0,05)$ & 0,90 & 1,00 & 1,11 \\
\hline & & Fark etmez (ref.) & 0,0 & & & \\
\hline & \multirow{4}{*}{$\begin{array}{l}\text { Dini inancin } \\
\text { yaşam } \\
\text { pratiklerindeki } \\
\text { etkisi }\end{array}$} & Etkili değil & $1,08(0,08)^{* * *}$ & 2,51 & 2,94 & 3,44 \\
\hline & & Düşük düzeyde etkili & $0,65(0,06)^{* * *}$ & 1,69 & 1,91 & 2,16 \\
\hline & & Orta düzeyde etkili & $0,19(0,05)^{* * *}$ & 1,08 & 1,20 & 1,34 \\
\hline & & Yüksek düzeyde etkili (ref.) & 0,0 & & & \\
\hline & \multirow[t]{3}{*}{ Tolerans düzeyi } & Tolerans var & $0,33(0,07)^{* * *}$ & 1,22 & 1,39 & 1,59 \\
\hline & & Kismi tolerans var & $0,07(0,04)^{*}$ & 0,99 & 1,08 & 1,17 \\
\hline & & Tolerans yok (ref.) & 0,0 & & & \\
\hline \multirow{16}{*}{ 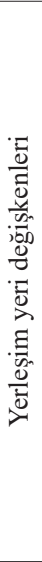 } & \multirow{4}{*}{$\begin{array}{l}15 \text { yaşına değin } \\
\text { yaşanan yerleşim } \\
\text { yeri }\end{array}$} & İl merkezi & $0,54(0,05)^{* * *}$ & 1,57 & 1,72 & 1,89 \\
\hline & & İlçe merkezi & $0,48(0,05)^{* * *}$ & 1,47 & 1,62 & 1,78 \\
\hline & & Yurt diş1 & $-0,10(0,14)$ & 0,75 & 0,99 & 1,31 \\
\hline & & Bucak veya köy (ref.) & 0,0 & & & \\
\hline & \multirow{12}{*}{ İBBS-12 } & İstanbul & $0,39(0,10)^{* * * *}$ & 1,21 & 1,48 & 1,80 \\
\hline & & Batı Marmara & $0,84(0,11)^{* * *}$ & 1,85 & 2,31 & 2,89 \\
\hline & & Ege & $0,61(0,10)^{* * *}$ & 1,52 & 1,85 & 2,25 \\
\hline & & Doğu Marmara & $0,72(0,10)^{* * *}$ & 1,67 & 2,05 & 2,51 \\
\hline & & Bat1 Anadolu & $0,64(0,10)^{* * *}$ & 1,56 & 1,89 & 2,30 \\
\hline & & Akdeniz & $0,30(0,11)^{* *}$ & 1,10 & 1,35 & 1,65 \\
\hline & & Orta Anadolu & $0,61(0,11)^{* * *}$ & 1,48 & 1,84 & 2,29 \\
\hline & & Batı Karadeniz & $0,33(0,12)^{* *}$ & 1,10 & 1,38 & 1,74 \\
\hline & & Doğu Karadeniz & $0,17(0,14)$ & 0,90 & 1,18 & 1,54 \\
\hline & & Kuzeydoğu Anadolu & $0,42(0,14)^{* *}$ & 1,16 & 1,52 & 1,99 \\
\hline & & Ortadoğu Anadolu & $0,56(0,12)^{* * *}$ & 1,39 & 1,75 & 2,20 \\
\hline & & Güneydoğu Anadolu (ref.) & 0,0 & & & \\
\hline
\end{tabular}

Not: $\mathrm{R}^{2}=0.17$ (Cox-Snell), 0.21 (Nagelkerke). Model $\chi^{2}(72)=4878,6$.

${ }^{*} \mathrm{p}<0,1, * * \mathrm{p}<0,05, * * * \mathrm{p}<0,001$ 
Tablo 5

Çocuktan Maddi Katkı Beklentisini Etkileyen Faktörler: 'Katılıyorum' Yerine 'Kısmen Katılyyorum'Deme Eğilimine İlişkin İsimsel Lojistik Regresyon Sonuçlart

\begin{tabular}{|c|c|c|c|c|c|c|}
\hline \multirow{2}{*}{\multicolumn{3}{|c|}{\begin{tabular}{|l}
$\begin{array}{l}\text { "Çocuk büyüdüğünde anne babasına maddi katkı } \\
\text { sağlamalıdır" }\end{array}$ \\
'Katılıyorum' yerine ' Kısmen katılmıyorum' eğilimi
\end{tabular}}} & \multirow[b]{2}{*}{ ( $\beta$ ) (SE) } & \multicolumn{3}{|c|}{$\begin{array}{c}\text { Odds oranları } \operatorname{Exp}(\beta) \text { için } \\
\text { Güven Aralıkları }\end{array}$} \\
\hline & & & & Alt & O.O. & Üst \\
\hline \multicolumn{3}{|c|}{ Sabit (intercept) } & $-2,73(0,11)^{* * * *}$ & & & \\
\hline \multirow{10}{*}{ 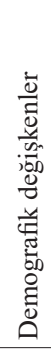 } & \multirow[b]{2}{*}{ Cinsiyet } & Kadın & $0,12(0,04)^{*}$ & 1,04 & 1,12 & 1,22 \\
\hline & & Erkek (ref.) & 0,0 & & & \\
\hline & \multirow{4}{*}{ Yaş } & -29 & $-0,01(0,08)$ & 0,84 & 0,99 & 1,16 \\
\hline & & $30-39$ & $0,02(0,05)$ & 0,92 & 1,02 & 1,13 \\
\hline & & $40-49$ & $-0,04(0,05)$ & 0,87 & 0,96 & 1,06 \\
\hline & & $50+($ ref. $)$ & 0,0 & & & \\
\hline & \multirow{4}{*}{ Çocuk sayısı } & Tek çocuk & $0,37(0,08)^{* * * *}$ & 1,24 & 1,44 & 1,68 \\
\hline & & 2 çocuk & $0,26(0,06)^{* * *}$ & 1,15 & 1,30 & 1,47 \\
\hline & & 3 çocuk & $0,19(0,06)^{* *}$ & 1,08 & 1,21 & 1,37 \\
\hline & & 4 veya daha fazla çocuk (ref.) & 0,0 & & & \\
\hline \multirow{10}{*}{ 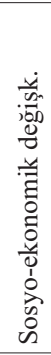 } & \multirow{4}{*}{$\begin{array}{l}\text { Tamamlanan } \\
\text { eğitim düzeyi }\end{array}$} & Üniversite veya üzeri & $0,47(0,11)^{* * *}$ & 1,30 & 1,61 & 1,98 \\
\hline & & Lise & $0,39(0,09)^{* * * *}$ & 1,24 & 1,48 & 1,78 \\
\hline & & İlkokul-Ortaokul-İlköğretim & $0,16(0,07)^{* *}$ & 1,02 & 1,18 & 1,35 \\
\hline & & Bir okul bitirmedi (ref.) & 0,0 & & & \\
\hline & \multirow{6}{*}{$\begin{array}{l}\text { Hanehalkı refah } \\
\text { düzeyi }\end{array}$} & En Yüksek & $0,91(0,12)^{* * * *}$ & 1,97 & 2,48 & 3,11 \\
\hline & & Yüksek & $0,64(0,10)^{* * * * *}$ & 1,56 & 1,89 & 2,29 \\
\hline & & Üst Orta & $0,47(0,09)^{* * * *}$ & 1,35 & 1,61 & 1,91 \\
\hline & & Alt Orta & $0,28(0,09)^{* * *}$ & 1,13 & 1,33 & 1,57 \\
\hline & & Düşük & $0,12(0,09)$ & 0,95 & 1,13 & 1,34 \\
\hline & & En düşük (ref.) & 0,0 & & & \\
\hline \multirow{10}{*}{ 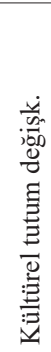 } & \multirow{3}{*}{$\begin{array}{l}\text { Tek çocuk için } \\
\text { cinsiyet tercihi }\end{array}$} & $\mathrm{K}_{1 \mathrm{z}}$ & $-0,09(0,05)^{*}$ & 0,83 & 0,91 & 1,01 \\
\hline & & Erkek & $-0,15(0,06)^{* *}$ & 0,77 & 0,86 & 0,97 \\
\hline & & Fark etmez (ref.) & 0,0 & & & \\
\hline & \multirow{4}{*}{$\begin{array}{l}\text { Dini inancin } \\
\text { yaşam } \\
\text { pratiklerindeki } \\
\text { etkisi } \\
\end{array}$} & \begin{tabular}{|l|} 
Etkili değil \\
\end{tabular} & $0,70(0,09)^{* * * *}$ & 1,70 & 2,02 & 2,40 \\
\hline & & Düşük düzeyde etkili & $0,60(0,07)^{* * * *}$ & 1,60 & 1,82 & 2,06 \\
\hline & & Orta düzeyde etkili & $0,12(0,06)^{* * *}$ & 1,01 & 1,13 & 1,26 \\
\hline & & Yüksek düzeyde etkili (ref.) & 0,0 & & & \\
\hline & \multirow{3}{*}{ Tolerans düzeyi } & Tolerans var & $0,05(0,08)$ & 0,89 & 1,05 & 1,23 \\
\hline & & Kismi tolerans var & $0,10(0,04)^{*}$ & 1,02 & 1,10 & 1,20 \\
\hline & & Tolerans yok (ref.) & 0,0 & & & \\
\hline \multirow{16}{*}{ 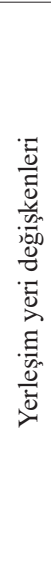 } & \multirow{4}{*}{$\begin{array}{l}15 \text { yaşıına } \\
\text { değin yaşanan } \\
\text { yerleşim yeri }\end{array}$} & İl merkezi & $0,37(0,05)^{* * * *}$ & 1,31 & 1,44 & 1,59 \\
\hline & & İlçe merkezi & $0,34(0,05)^{* * * * *}$ & 1,28 & 1,41 & 1,55 \\
\hline & & Yurt diş1 & $0,02(0,15)$ & 0,77 & 1,02 & 1,36 \\
\hline & & Bucak veya köy (ref.) & 0,0 & & & \\
\hline & \multirow{12}{*}{ İBBS-12 } & İstanbul & $-0,26(0,09)^{* * *}$ & 0,64 & 0,77 & 0,92 \\
\hline & & Batı Marmara & $0,39(0,10)^{* * * *}$ & 1,21 & 1,47 & 1,79 \\
\hline & & Ege & $-0,08(0,09)$ & 0,78 & 0,92 & 1,10 \\
\hline & & Doğu Marmara & $-0,35(0,10)^{* * * *}$ & 0,58 & 0,71 & 0,86 \\
\hline & & Batı Anadolu & $-0,18(0,09)^{* * *}$ & 0,70 & 0,83 & 0,99 \\
\hline & & Akdeniz & $-0,17(0,09)^{*}$ & 0,70 & 0,84 & 1,01 \\
\hline & & Orta Anadolu & $-0,20(0,10)^{*}$ & 0,67 & 0,82 & 1,00 \\
\hline & & Batı Karadeniz & $-0,43(0,11)^{* * *}$ & 0,53 & 0,65 & 0,81 \\
\hline & & Doğu Karadeniz & $-0,31(0,12)^{* * *}$ & 0,58 & 0,73 & 0,93 \\
\hline & & Kuzeydoğu Anadolu & $-0,38(0,14)^{* * *}$ & 0,52 & 0,68 & 0,90 \\
\hline & & Ortadoğu Anadolu & $-0,56(0,13)^{* * * *}$ & 0,45 & 0,57 & 0,73 \\
\hline & & Güneydoğu Anadolu (ref.) & 0,0 & & & \\
\hline
\end{tabular}

Not: $\mathrm{R}^{2}=0.17$ (Cox-Snell), 0.21 (Nagelkerke). Model $\chi^{2}(72)=4878,6$.

$* \mathrm{p}<0,1, * * \mathrm{p}<0,05, * * * \mathrm{p}<0,001$ 


\section{Kültürel tutum değişkenleri:}

Tek çocuk için cinsiyet tercihi: Tek çocuk sahibi olması durumunda çocuğun cinsiyeti için 'farketmez' kategorisi referans olarak alındı ğında, kız çocuk tercih eden cevaplayıcıların 'katılmıyorum' deme yönündeki eğilimleri $\% 14\left(\beta=0,13\right.$, Wald $\chi^{2}$ $(1)=7,7, p=0.06)$ daha yüksektir.

'Kısmen katılma' eğiliminde ise en yüksek odds oranı referans kategorisi olan 'farketmez' kategorisindedir. Tek çocuk için erkek çocuk tercihini dile getiren cevaplayıcıların 'kısmen katılıyorum' deme odds oranı 0,86 ' dır (\%14 daha düşük) ( $\beta$ $=-0,15$, Wald $\left.\chi^{2}(1)=6,4, p=0.01\right)$.

Dini inancin yaşam pratiklerindeki etkisi: 'Katılmıyorum' veya 'Kısmen katılıyorum' deme eğilimiyle dini inancın yaşam pratiklerine etki etme düzeyi arasında negatif yönlü ve anlamlı bir ilişki bulunmuştur. Bu değişkende 'yüksek düzey' referans kategorisi olarak alındığında, 'etkili değil' diyenlerin ifadeye 'katılmıyorum' deme odds oranı neredeyse 3 misli $\left(\beta=1,08\right.$, Wald $\left.\chi^{2}(1)=180,2, p=0,00\right)$, 'kısmen kat1lyorum' deme odds oranı da 2 misli $\left(\beta=0,70\right.$, Wald $\left.\chi^{2}(1)=62,7, p=0,00\right)$ daha fazladır.

Tolerans düzeyi: Kadın ve erkek birlikteliği ve evliliğinde farklılıklara yönelik tolerans gösterilmesini ifade eden 'tolerans var' kategorisinde, 'katılmıyorum' deme eğilimi, referans kategorisi olan 'tolerans yok' düzeyindekine göre neredeyse $\% 40$ daha fazladır $\left(\beta=0,33\right.$, Wald $\left.\chi^{2}(1)=23,1, p=0,00\right)$. Diğer bir deyişle, toleranslı tutum sahibi olanların çocuk büyüdüğünde anne babasına maddi katkı sağlamalıdır ifadesine katılmama yönündeki eğilimi, tolerans sahibi olmayanlardan anlamlı derecede daha yüksektir. Bu ilişki biçimi ‘kısmen katılıyorum' ifadesinde de gözlenmemektedir.

\section{Yerleşim yeri değişkenleri:}

15 yaşına değin yaşanan yerleşim yeri: 15 yaşına değin daha uzun süre 'il merkezi' ve 'ilçe merkezi' gibi kentsel yerleşim yerlerinde yaşamış olan cevaplayıcıların 'katılmıyorum' veya 'kısmen katılıyorum' deme eğilimi, bu yaşa değin daha çok 'bucak veya köy yerleşim' yerlerinde yaşayanlardan anlamlı düzeyde yüksektir. 15 yaşına değin daha çok 'il merkezinde' yaşamış olanların 'katılmıyorum' deme odds oranı $1,72\left(\beta=0,54\right.$, Wald $\left.\chi^{2}(1)=128,7, p=0,00\right)$ ve 'k1smen kat1lyorum' deme odds oran 1 da 1,44 'dür $\left(\beta=0,37\right.$, Wald $\left.\chi^{2}(1)=54,1, p=0,00\right) .15$ yaşına değin daha çok ilçe merkezinde yaşamış olanların odds oranları da referans kategorisine göre daha yüksek düzeydedir.

IBBS-12: Cevaplayıcının araştırmanın gerçekleştirildiği dönemde yaşadığı bölgeyi temsil eden bu değişkende 'Güneydoğu Anadolu' bölgesi referans kategori olarak alınmıştır. Çocuktan maddi katkı beklentisine 'katılmıyorum' deme eğilimi diğer tüm bölgelerde referans kategorisindekine göre daha yüksektir. Özellikle 'Batı' ve 'Doğu 
Marmara' bölgelerinde odds oranları referans kategorisine göre 2 katıdan daha fazladır; sirasiyla $\left(\beta=0,84\right.$, Wald $\left.\chi^{2}(1)=53,8, p=0,00\right)$ ve $\left(\beta=0,72\right.$, Wald $\chi^{2}(1)=47,6, p=$ 0,00). Bu bölgeleri sirasıyla Batı Anadolu, Ege, Orta Anadolu, Ortadoğu Anadolu Kuzeydoğu Anadolu, İstanbul, Batı Karadeniz, Akdeniz ve Doğu Karadeniz bölgeleri izlemektedir.

'Kısmen katılıyorum' odds oranları ise farklı bir görünüm arz etmektedir. 'Batı Marmara' bölgesi dışındaki diğer tüm bölgelerde 'kısmen katılıyorum' deme eğilimi Güneydoğu Anadolu'dakinden daha düşük düzeydedir. Yani, Güneydoğu Anadolu bölgesinde 'katılıyorum' yerine 'kısmen katılıyorum' cevabını verme eğilimi ‘Batı Marmara' bölgesi dışındaki diğer bölgelerdekinden yüksektir.

\section{Değerlendirme ve Sonuç}

Çalışmamızın veri analizi bölümünde "Çocuk büyüdüğünde anne babasına maddi katkı sağlamalıdır” ifadesine 'katılmama' veya 'kısmen katılma' eğilimleri ile ilişkili faktörler incelenmiştir. Bu faktörler katılımcıların 'demografik', 'sosyo-ekonomik', 'kültürel tutum' ve 'yerleşim yeri’ özelliklerine göre gruplanarak ele alınmıştır.

Türkiye' de zamanla çalışan kadınların oranı artıış olmasına karşın halen kadınların büyük çoğunluğu çalışma yaşamında yer almamaktadır. Bu durumdan dolayı kadınların büyük bölümü doğrudan sosyal güvenceye sahip değillerdir. Dolayısıyla, Türkiye'de kadınlar genel olarak erkeklere nispeten daha düşük gelire sahiptir ve daha çok eşleri veya babaları dolayısıyla sosyal güvence kapsamında yer almaktadırlar. Bununla birlikte, model bulgularının gösterdiği üzere çocuğun anne babasına maddi katkısını kabul etmeme eğilimi -diğer tüm değişkenler kontrol altında tutulmasına rağmenkadınlarda erkeklerden daha yüksektir. Kadınların görece olumsuz koşullarına rağmen, söz konusu geleneksel sosyal kabulün değişimine erkeklerden daha eğilimli olmaları dikkat çekici bir bulgudur.

Yaş kuşaklarının ve farklı sayıda çocuk sayısına sahip katılımcıların konuya yaklaşımları değerlendirildiğinde, model bulgularımız ile daha önceki çalışmaların bulgularının örtüşmekte olduğu görülmektedir. Orta veya yaşlı kuşak olarak kabul edebileceğimiz yaşlara henüz ulaşmamış olan ve 'bir veya iki' çocuk sahibi katılımcıların çocuklardan ekonomik beklenti içinde olma eğilimleri daha düşüktür. Benzer durum çalışmamızda kullandığımız sosyo-ekonomik değişkenler ve yerleşim yeri özellikleri için de geçerlidir; daha yüksek eğitim ve refah düzeyi, daha uzun süre ve daha yoğun kentsel yerleşim yerlerinde yaşama özellikleri katılımcıların çocuk büyüdüğünde maddi katkı bekleme eğilimini belirgin şekilde azaltmaktadır. Sosyo-ekonomik değişkenler kurduğumuz modelde değişimin neredeyse \%40’lık kısmını açıklayarak modele en çok katk1 yapan değişkenler olmuştur. Bu bulgu da daha önceki çalışmaların sonuçları ile örtüşmektedir. 
Modelimizde kullandığımız kültürel tutum değişkenlerinin etkisine baktığımızda; özellikle daha seküler ve tolerans düzeyi daha yüksek katılımcıların, daha dindar ve daha az toleranslı katılımcılardan 'çocuktan ekonomik beklenti içinde olmama' anlamında ayrıştığını göstermektedir. Dolayısıyla, sosyo-ekonomik koşulları aynı olan bireyler arasında dahi farklı kültürel tutum ve düşüncelere sahip olmak, çocuğa ilişkin algı ve beklentileri farklılaştıran etki oluşturabilir. Kanımızca mevcut çalışmanın konuyla ilişkili alanyazına yaptığı en özgün katkı da bu bulgudur. Böylelikle, çocuğa ilişkin atfedilen değerlerin ve algıların ele alındığı çalışmalarda sosyo-kültürel eğilim ve tutumların, sosyoekonomik faktörler ve yerleşim yeri özellikleri etkilerinden bağımsız şekilde dikkate alınması gerektiği anlaşılmaktadır.

Sonuç olarak çalışmamız, Türkiye'de demografik geçişin, eğitim düzeyinin, ekonomik kalkınma ve refahın arttı̆̆ı, sekülerleşme ve evliliklerle ilgili farklılıklara toleransın yaygınlaştığı, nüfusun daha fazla kentleştiği koşullarda aile yapısında ortaya çıkan en dikkate değer değişim ve farklılıklardan birisinin de çocuktan ekonomik beklentilerin azalması olduğunu göstermektedir. Nitekim bu durum günümüzde küreselleşen tüketim dünyası koşullarında çocukların maddi fayda sağlamak bir yana, kendilerine masraf yapılan tüketici bir özneye dönüşmüş olmaları gerçeği ile yakın olarak ilişkilidir.

Türkiye'de modernleşme dinamikleriyle birlikte, sosyo-ekonomik statüsü yüksek, daha eğitimli, seküler ve tolerans seviyesi yüksek bireylerde daha fazla olmak üzere, çocuğun özerkliğine, bireysel yaşantısına ve başarısına verilen önemin artmasına bağlı olarak maddi fayda beklentisinin azaldığına işaret edilebilir. Türkiye'de son on yıllardaki ekonomik kalkınma ve refah artışı ve eğitimdeki gelişmeler ve kentleşme süreçleriyle birlikte aile yapısında ortaya çıkan en dikkate değer değişim ve farklılık, çocuğun yaşl11ık güvencesi değerini de içine alacak şekilde, çocuktan beklenen faydacı ve ekonomik değerin azalmasıdır. Buna karşın, çocuğun psikolojik değerinde kayda değer bir artış dikkat çekmektedir.

Hakem Değerlendirmesi: Dış bağımsız.

Çıkar Çatışması: Yazarlar çıkar çatışması bildirmemiştir.

Finansal Destek: Yazarlar bu çalışma için finansal destek almadıklarını beyan etmiştir.

Peer-review: Externally peer-reviewed.

Conflict of Interest: The authors have no conflict of interest to declare.

Grant Support: The authors declared that this study has received no financial support. 


\section{Kaynakça/References}

Aile ve Sosyal Politikalar Bakanlığı. (2014a). Türkiye aile yapısı araştırması 2006 (2. bs.). Ankara: Yazar.

Aile ve Sosyal Politikalar Bakanlığı. (2014b). Türkiye aile yapısı araştırması 2011. Ankara: Yazar. Aile ve Sosyal Politikalar Bakanlığı. (2015). Türkiye’de evlilik tercihleri. Ankara: Yazar.

Aysan, M. F. (2018). Nesiller arası transferin değişimi ve mutluluğa etkisi. Yasemin Esen ve Cenap Nuhrat (Ed.), Türkiye aile yapısı ileri istatistik analizi içinde (s. 314-333). Ankara: Aile, Çalışma ve Sosyal Hizmetler Bakanlığı.

Başbakanlık Aile ve Sosyal Politikalar Genel Müdürlüğü. (2010). Türkiye'de aile değerleri araștırması. Ankara: Manas Medya.

Bayram, N. (2004). Sosyal bilimlerde SPSS ile veri analizi. Bursa: Ezgi Kitapevi.

Beșpınar, F. U. ve Beşpınar, L. Z. (2018). Türkiye'de orta üst sınıf laik ve muhafazakâr kimliklerin babalık deneyimleri üzerinden irdelenmesi: Benzerlikler, farklılıklar, önyargılar ve mesafeler. Toplum ve Bilim, 143, 5-43.

Can, A. (2014). SPSS ile bilimsel araştırma sürecinde nicel veri analizi (3. bs.). Ankara: Pegem Akademi.

Chan, Y. H. (2005). Multinomial logistic regression. Singapore Medical Journal, 46(6), 259-268.

Field, A. (2018). Discovering statistics using IBM SPSS statistics. London, UK: Sage.

Fişek, G. O. (2005). Gelenekten değişime Türkiye'de aile ve ergenler. Adolesan Sağll̆ğ Sempozyum Dizisi, 43, 39-49.

Hacettepe Üniversitesi Nüfus Etütleri Enstitüsü. (2014). 2013 Nüfus ve sağlık araştırması. Ankara: Yazar.

Hacettepe Üniversitesi Nüfus Etütleri Enstitüsü. (2019). 2018 Nüfus ve sağlık araştırması. Ankara: Yazar.

IBM Knowledge Centre. (2019) Stepwise multinominal regression, 2019. Retrieved from https://www.ibm.com/support/knowledgecenter/en/SSLVMB_24.0.0/spss/tutorials/nom_telco stepwise.html

Inglehart, R., \& Baker, W. E. (2000). Modernization, cultural change and the persistence of traditional values. American Sociological Review, 65(1), 19-51.

Kağıtçıbaşı, Ç. (2017). Benlik, aile ve insan gelişimi: Kültürel psikolojide kuram ve uygulamalar. İstanbul: Koç Üniversitesi Yayınları.

Kağıtçıbaşı, Ç. (2000). Kültürel psikoloji: Kültür bağlamında insan ve aile (2. bs.). İstanbul: Evrim Yayınevi.

Kağıtçıbaş1, Ç. (1981). Çocuğun değeri: Türkiye'de değerler ve doğurganlık. İstanbul: Boğaziçi Üniversitesi İdari Bilimler Fakültesi Yayınları.

Kağıtçıbaşı, Ç., \& Ataca, B. (2005). Value of children and family change: A three-decade portrait from Turkey. Applied Psychology: An International Review, 54(3), 317-337.

Kağıtçıbaşı, Ç. ve Ataca, B. (2017). Çocuğun değeri ve aile değişimi: Türkiye'den otuz yıllık bir portre. Sosyoloji Dergisi, 35, 77-101.

Kalaycığlu, S., Çelik, K., Çelen, Ü., ve Türkyılmaz, S., (2010). Temsili bir örneklemde sosyoekonomik statü (ses) ölçüm aracı geliştirilmesi: Ankara Kent Merkezi Örneği. Sosyoloji Araştırmaları Dergisi, 13(1), 183-220. 
Koç, İ., Eryurt, M. A., Adal1, T. ve Seçkiner, P. (2010). Türkiye'nin demografik dönüşümü, doğurganlık, aile planlaması, anne-çocuk sağliğl ve beş yaş altı ölümlerdeki değişimler: 1968-2008. Ankara: Hacettepe Üniversitesi Nüfus Etütleri Enstitüsü.

Koç, İ. (2018). Türkiye'de aile yapısının değişimi sürecinde tek ebeveynli ailelerin oluşumu, belirleyicileri ve refah durumu (2006-2016). Y. Esen ve C. Nuhrat (Ed.), Türkiye aile yapısı ileri istatistik analizi içinde (s. 33-85). Ankara: Aile, Çalışma ve Sosyal Hizmetler Bakanlığı.

Koç, İ. (2014). Türkiye'de aile yapısının değişimi:1968-2011. Türkiye'de aile yapısı tespitler ve öneriler içinde (s. 24-55). İstanbul: Aile ve Sosyal Politikalar Bakanlı̆̆ı, Aile ve Toplum Hizmetleri Genel Müdürlüğü.

Koçkar, A. İ. ve Harma, M. (2018). Aile içi anlaşmazlıklar, çocuğa yansımaları ile çocuğun değerinin yıllar içerisinde değişimi. Y. Esen ve C. Nuhrat (Ed.), Türkiye aile yapısı ileri istatistik analizi içinde (s. 136-179). Ankara: Aile, Çalışma ve Sosyal Hizmetler Bakanlığı.

Kumar, R. (2011). Research methodology, a step by step guide to beginner (3rd ed.). London, UK: Sage.

Laerd Statistics. (2018). Multinomial logistic regression using SPSS Statistics, 2018. Retrieved from https://statistics.laerd.com/spss-tutorials/multinomial-logistic-regression-using-spss-statistics. php

National Centre for Research Methods. (2011). Using statistical regression methods in education research, 4.6. how good is the model? Retrieved from http://www.restore.ac.uk/srme/www/fac/ soc/wie/research-new/srme/modules/mod4/6/index.html

Özbay, F. (2015). Dünden bugüne aile, kent ve nüfus. İstanbul: İletişim Yayınları.

Öztan, E. (2014). Türkiye' de ailecilik, biyosiyaset ve toplumsal cinsiyet rejimi. Toplum ve Bilim, 130, 176-189.

Pamuk, Ş. (2014). Türkiye'nin 200 ylllık iktisadi tarihi. İstanbul: Türkiye İş Bankası Kültür Yayınları.

Retherford, R., \& Choe, M. K. (1993). Statistical model for causal analysis. New York, NY: John Wiley \& Sons.

Rossi, M. S. (2011). Examining the relationship and influence of infant temperament and marital satisfaction on parenting. Pennsylvania, PA: Pennsylvania State University Press

Rutstein, S. O., \& Kiersten, J. (2004). The DHS wealth index. DHS Comparative Reports No. 6. Calverton, MD: ORC Macro.

Sunar, D., \& Fişek, G. O. (2005). Contemporary Turkish families. In J. L. Roopnarine \& U.P. Gielen (Eds.), Families in global perspective. Boston, MA: Pearson Education.

Topçu, G. (2018). Varsayılan aile kıskacında babalık: Türkiye'de farklı babalık algıları ve sosyal politika ilişkisi. Toplum ve Bilim, 145, 54-102.

Türkiye İstatistik Kurumu. (2016a). Cinsiyet, yaş grubu, öğrenim durumu, IBBBS 1.Düzey ve üç büyük ile göre çocuk ile ilgili algılar, 2016. http://www.tuik.gov.tr/PreTablo.do?alt_id=1068

Türkiye İstatistik Kurumu. (2016b). Aile Yapısı Araştırması, 2016. http://tuik.gov.tr/MicroVeri/ Aile_2016/turkce/index.html

Türkiye İstatistik Kurumu. (2018a). Gayrisafi yurt içi hasıla, iktisadi faaliyet kollarına (A21) göre cari fiyatlarla değer, pay, değişim oranı, 1998-2018, 2018a. http://www.tuik.gov.tr/PreTablo. do?alt_id=1108 
Türkiye İstatistik Kurumu. (2018b). Kiş̧i Başına Gayri Safi Yurtiçi Hasıla, Kişi Başına Gayri Safi Yurtiçi Hasıla, 2018b, http://www.tuik.gov.tr/PreTablo.do?alt_id=1108 (erişim, 11.10.2019).

Türkiye İstatistik Kurumu. (2018c). Ístatistiki Bölge Birimleri Sinıflamasına göre ortalama evlenme yaşı, 2018c, http://www.tuik.gov.tr/PreTablo.do?alt_id=1060 (erişim, 19.10.2019).

Türkiye İstatistik Kurumu. (2018c). Adrese Dayalı Nüfus Kayıt Sistemi sonuçları, 2018c, http://www.tuik.gov.tr/PreHaberBultenleri.do?id=30709 (erişim, 01.08.2019).

Türkiye İstatistik Kurumu. (2019a). Hayat Tablolarl, 2016-2018. 2019, http://www.tuik.gov.tr/PreHaberBultenleri.do?id=30712 (erişim, 01.11.2019).

Türkiye İstatistik Kurumu. (2019b). Ístatistiklerle Aile, 2019, http://www.tuik.gov.tr/PreHaberBultenleri.do?id=30726 (erişim, 07.11.2019).

Türkiye İstatistik Kurumu. (2019c). Doğum İstatistikleri, 2018, 2019. http://www.tuik.gov.tr/ PreHaberBultenleri.do?id=30696

Türkiye İstatistik Kurumu. (2019d). Evlenme ve Boşanma İstatistikleri, 2018, 2019, http://www.tuik.gov.tr/PreHaberBultenleri.do?id=30698 (erişim, 07.11.2019).

Vyas, S., \& Kumaranayake, L. (2006). Constructing socio-economic status indices: How to use principal components analysis. Health Policy and Planning, 21(6), 459-468.

Yavuz, S. (2002). Household composition and complexity in Turkey: Findings from the Turkish Demographic and Health Survey 1998 (Yüksek lisans tezi, Hacettepe Üniversitesi, Nüfus Etütleri Enstitüsü, Ankara). https://tez.yok.gov.tr/UlusalTezMerkezi/

Yavuz, S. ve Özmete, E. (2012). Türkiye'de genç bireyler ve ebeveynleri arasında yaşanan sorunların "aile yapısı araştırması" sonuçlarına göre değerlendirilmesi. Sosyal Politika Çalışmaları, 7(29), 9-28.

Zeybek, S. O. (2013). Bu bebeğin annesi nerede? Cinsiyet, babalık ve armağan ilişkileri. Toplum ve Bilim, 126, 120-144. 
